PONTIFícIa UNIVERSIDADE CATÓlicA do RIO dE JANEIRO

\title{
E-SPORTS: BARREIRAS AO DESENVOLVIMENTO NO BRASIL
}

Anderson Oliveira Correia

Trabalho de Conclusão de Curso

Centro de CIÊNCIAS SOCIAIS - CCS

DEPARTAMENTO DE ADMINISTRAÇÃO

Graduação em Administração de Empresas 
Trabalho de Conclusão de Curso, apresentado ao programa de graduação em Administração da PUC-Rio como requisito parcial para a obtenção do título de graduação em Administração.

Orientador: Martim Francisco de Oliveira e Silva 
"Qualquer semelhança dos e-sports com os esportes já reconhecidos há muitos anos pode não ser mera coincidência."

Anderson "Anderoc" Correia 


\section{Agradecimentos}

Em primeiro lugar agradeço a minha família, por ter estado ao meu lado até aqui, por ter apoiado e aconselhado cada decisão minha, e com isso possibilitando que eu chegasse até esse momento da minha vida.

Ao meu pai, que com sua inteligência e percepção do mundo que admiro, invejo e espero um dia chegar minimamente a metade, sempre me aconselhou a seguir o caminho correto para que eu não me perdesse pelas vias aparentemente mais fáceis da vida.

A minha mãe, que com seu jeito único de ser, jamais deixou de ser um exemplo de amor e dedicação, estando sempre presente, me apoiando constantemente até mesmo quando eu não fazia por onde.

Ao meu irmão Fábio o qual eu acredito ser muito mais parecido do que nossa mãe diz, pelo seu jeito divertido que acredito ter influenciado muito no meu jeito de ser.

Ao meu sobrinho Mateus e primo Victor que além de parentes são grandes amigos, e certamente possuem grande influência sobre minha vida pessoal e possivelmente profissional no futuro.

Minhas avós Margarida e Maria José, minha tia Myriam e prima Mirinha, jamais esquecerei todas vocês, pois são muito importantes no que sou hoje e espero que de alguma forma as tenha deixado orgulhosas com essa conquista.

Ao meu eterno irmão Kiko que esteve comigo por diversos anos, jamais te esquecerei. Sempre ao meu lado, seja brigando, me abraçando nos momentos difíceis e também me acordando nas manhãs complicadas com seu jeito único de ser.

A minha grande amiga Talita, que insistiu para que eu me dedicasse em busca do ensino superior, que me serviu de exemplo no decorrer da faculdade, e que esteve ao meu lado em diversos momentos me apoiando, como grande 
companheira e cúmplice durante os anos. Muito obrigado pela sua contribuição para que eu chegasse até aqui.

A Pontifícia Universidade Católica do Rio de Janeiro, instituição que certamente mudou minha vida, que me permitiu enxergar o mundo como enxergo hoje, que me ensinou e consolidou conceitos tanto do curso de administração, quanto da vida. Além de ter me permitido formar opiniões e amizades que não seriam possíveis sem essa instituição.

Aos professores do IAG que atuaram na minha formação apresentando muito mais do que o conteúdo da administração, mas também diferentes perspectivas relevantes para o meu futuro profissional e pessoal. Destaco os professores Andréa Cherman e Roberto Gil Uchoa, com os quais persisti em buscar matérias o quanto foi possível, pois apesar de sempre terem sido carrascos, sempre me fizeram buscar o máximo de mim, e sem dúvida se destacaram na formação da pessoa e do profissional que espero ser.

Ao meu orientador Martim Francisco que abraçou a causa desta monografia desde o primeiro dia, jamais me deixando desamparado do seu apoio e dedicação na produção deste trabalho. Continue sempre este profissional dedicado para que outros tenham a sorte que eu tive de ter a sua incrível orientação.

Aos meus amigos, que tornaram o caminho até aqui muito mais fácil e divertido, que muito me ensinaram e que certamente contribuíram na minha formação e preparação para a vida. Meu sincero muito obrigado a todos vocês.

Por fim, obrigado a todos os entrevistados que cederam seu tempo em prol deste trabalho. Sem a ajuda de vocês a produção deste não seria possível, e espero estar retribuindo as suas contribuições com essa colaboração ao cenário brasileiro de e-sports. 


\section{Resumo}

CORREIA, Anderson O. E-sports: barreiras ao desenvolvimento no Brasil. Rio de Janeiro, 2017. Número de páginas 54. Trabalho de Conclusão de Curso - Departamento de Administração. Pontifícia Universidade Católica do Rio de Janeiro.

A indústria dos e-sports, como o League of Legends, está dando seus primeiros passos no Brasil, onde está em fases iniciais de desenvolvimento quando comparada à América do Norte, Europa e Ásia. No Brasil o desenvolvimento da indústria dos e-sports enfrenta como principais obstáculos a atual situação econômica do país, a demografia peculiar da população, falta de infraestrutura oferecida pelas fornecedoras de serviços de internet, mídia tendenciosa e até mesmo o preconceito por parte da população. Estas barreiras têm dificultado o crescimento do setor no país, tal como o desenvolvimento dos seus profissionais. Há caminhos para superar essas barreiras, e para isso são necessários investimentos e ações pelos envolvidos na área.

Palavras-chave

E-sports, Indústrias emergentes, estratégia 


\section{Abstract}

The e-sports industry, such as the League of Legends, is taking its first steps in Brazil, where it is in early stages of development when compared to North America, Europe and Asia. In Brazil the development of the e-sports industry faces as obstacles the current economic situation of the country, the peculiar demographics of the population, lack of infrastructure offered by internet service providers, biased media and even prejudice by the population. These barriers have hampered the growth of the sector in the country as the development of its professionals. There are some ways to overcome these barriers, and for that investments and actions by those involved in the area are needed.

\section{Key-words}

E-sports, emerging industries, strategy 


\section{Sumário}

1. Apresentação do tema e objetivos do estudo 1

1.1. Introdução 1

1.1.1. Desenvolvimento recente 1

1.1.2. Destaques no mundo 4

1.1.3. Reconhecimento do e-sport no Brasil 4

1.2. Questão do estudo 5

1.3. Objetivo Final 5

1.4. Objetivos intermediários 6

1.5. Delimitação e foco do estudo 6

1.6. Relevância 6

2. Referencial Teórico 7

$\begin{array}{ll}\text { 2.1. } 0 \text { e-sport } & 7\end{array}$

2.2. Esporte $\quad 8$

2.3. Indústrias emergentes 9

2.3.1. Estratégias competitivas em indústrias emergentes 9

2.3.2. Problemas que restringem o desenvolvimento das indústrias $\begin{array}{ll}\text { emergentes } & 10\end{array}$

2.3.2.1. Ausência de infraestrutura 10

2.3.3. Mercados iniciais e posteriores $\quad 11$

2.3.4. Escolhas estratégicas 12

2.3.4.1. Exterioridades no desenvolvimento das indústrias 12

2.3.4.2. Mudança de papel dos canais 12

2.3.5. Oportunidades de entrada 13

2.4. Substituição como meio de entretenimento 13

2.4.1. Identificação de substitutos $\quad 13$

2.4.2. Mudança na percepção de valor do comprador 14 
3 . Metodologia 15

3.1. Tipo de pesquisa $\quad 15$

3.1.1. Quanto aos fins 15

3.1.2. Quanto aos meios 15

3.2. Universo e amostra 15

3.3. Seleção da amostra 16

3.4. O procedimento de coleta de dados 16

3.5. Tratamento de dados 16

3.6. Limitações do método 17

4. Apresentação e análise dos resultados 18

4.1. 0 e-sport 18

4.2. Preconceito no e-sport $\quad 19$

4.3. As barreiras enfrentadas pelos e-sports no Brasil 22

4.3.1. Barreiras econômicas 22

4.3.2. Esforço físico 25

4.3.3. Barreiras demográficas e de infraestrutura 27

4.3.4. Mídia tendenciosa 29

4.4. Formas de superação das barreiras $\quad 30$

4.4.1. Superando as barreiras econômicas 31

4.4.2. Superando o preconceito 32

4.4.3. Superando as barreiras demográficas e de infraestrutura 33

4.4.4. Superando as barreiras da mídia tendenciosa 33

4.5. Interesse das organizações esportivas nos e-sports 34

5. Conclusões 37

5.1. Recomendações para novos estudos 39

6. Bibliografia 41

6.1. Anexos 44

6.1.1. Questionário 44 


\section{Apresentação do tema e objetivos do estudo}

\subsection{Introdução}

Com origem na década de 70 e de forma amadora, surgiram os e-sports (esportes eletrônicos), que originalmente eram competições locais de jogos eletrônicos da época, e com o passar dos anos foram se desenvolvendo e tornando-se mais populares conforme crescia a acessibilidade da população aos consoles (videogames).

Na década de 90 com o crescimento da rede mundial de computadores e a possibilidade de interação remota entre as pessoas de forma instantânea, surgiram, também, os campeonatos de e-sports online, em que jogadores de várias nacionalidades disputavam torneios de jogos populares daquela época, como Warcraft, Starcraft, Quake e Counter-Strike, jogos que exigem estratégias e reflexos aprimorados, baseados em muito tempo de treinamento.

\subsubsection{Desenvolvimento recente}

Ao desenrolar dos anos do novo milênio, os computadores e o acesso à internet tornaram-se presentes no dia a dia de massiva parte da população mundial. Com isso, os e-sports foram se popularizando, até chegarem aos dias atuais com transmissões mundiais através de plataformas de vídeos online, como o Youtube ou outras especializadas na transmissão da modalidade como a Twitch Tv, além de canais esportivos em diversos países onde se faz presente.

Como se pode perceber, os e-sports são, desde sua origem, bastante dependentes do desenvolvimento tecnológico dos consoles, meios de comunicação e plataformas de transmissão. Com a constante evolução dessas tecnologias, os e-sports também continuam a evoluir, caracterizando-se, atualmente, como uma indústria emergente. Segundo Porter (2004, p. 223), "indústrias emergentes são indústrias recentemente formadas, ou reformadas, criadas por inovações tecnológicas, alterações nas relações de custos relativos, surgimento de novas necessidades dos consumidores ou outras alterações econômicas e sociais que elevam um novo produto ou serviço em nível de uma oportunidade potencialmente viável de negócio". 
O mercado de e-sports vem crescendo mundialmente ao longo dos últimos anos. Segundo dados da Superdata Research, em 2015 os e-sports movimentaram US\$ 750 milhões, e, no ano de 2016, US\$ 890 milhões de dólares, distribuídos pela América do Norte (US\$ 275 milhões dólares), Europa (US\$ 269 milhões de dólares), Ásia (US\$ 328 milhões de dólares) e "resto do mundo" (US\$ 19 milhões de dólares), como se pode observar no Gráfico 1. Há previsões de que o segmento alcance receitas de US $\$ 1.23$ bilhão de dólares até o ano de 2019, como se pode observar no Gráfico 2. (Superdata Research, 2016).

\section{Gráfico 1 - Receita dos e-sports no mundo por região}

Worldwide eSports revenues by region, 2016E

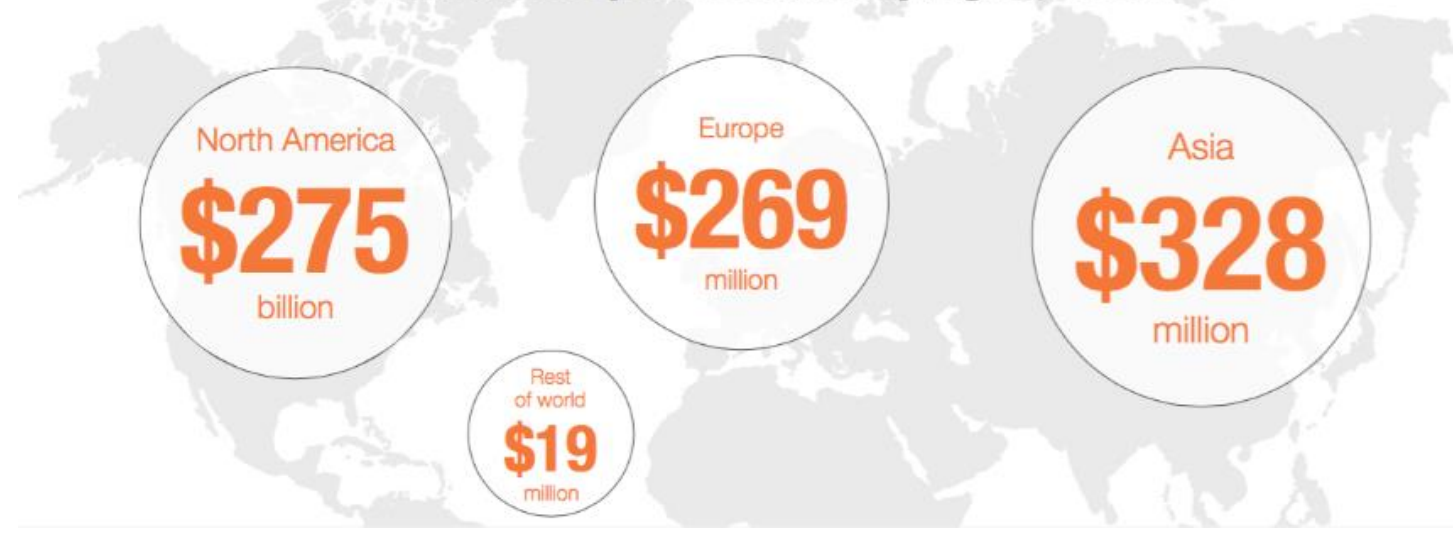

Fonte: Superdata Research, 2016

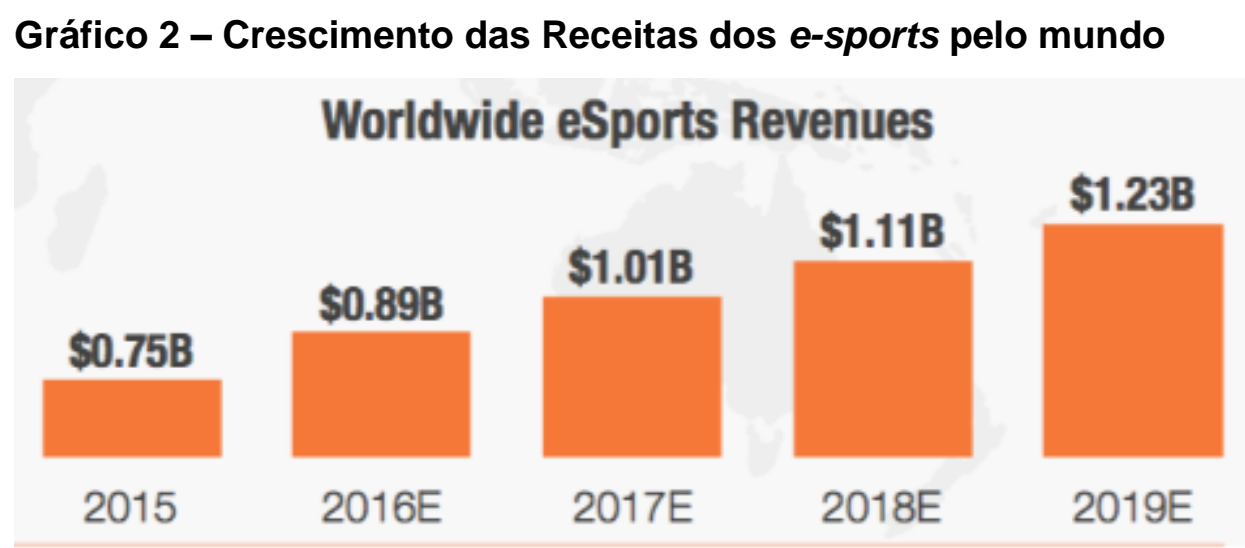

Fonte: Superdata Research, 2016

De acordo com a Superdata Research, em 2015 havia 188 milhões de espectadores de e-sports no mundo, número que deveria crescer para 303 milhões até o ano de 2019, como indicado no Gráfico 3. A expectativa de crescimento possuía base no aumento da divulgação e na maior participação dos e-sports na programação dos canais esportivos de televisão, cada vez mais receptivos à novidade. (Superdata Research, 2016). 


\section{Gráfico 3 - Número de espectadores de e-sports pelo mundo}

\section{Worldwide eSports Audience}

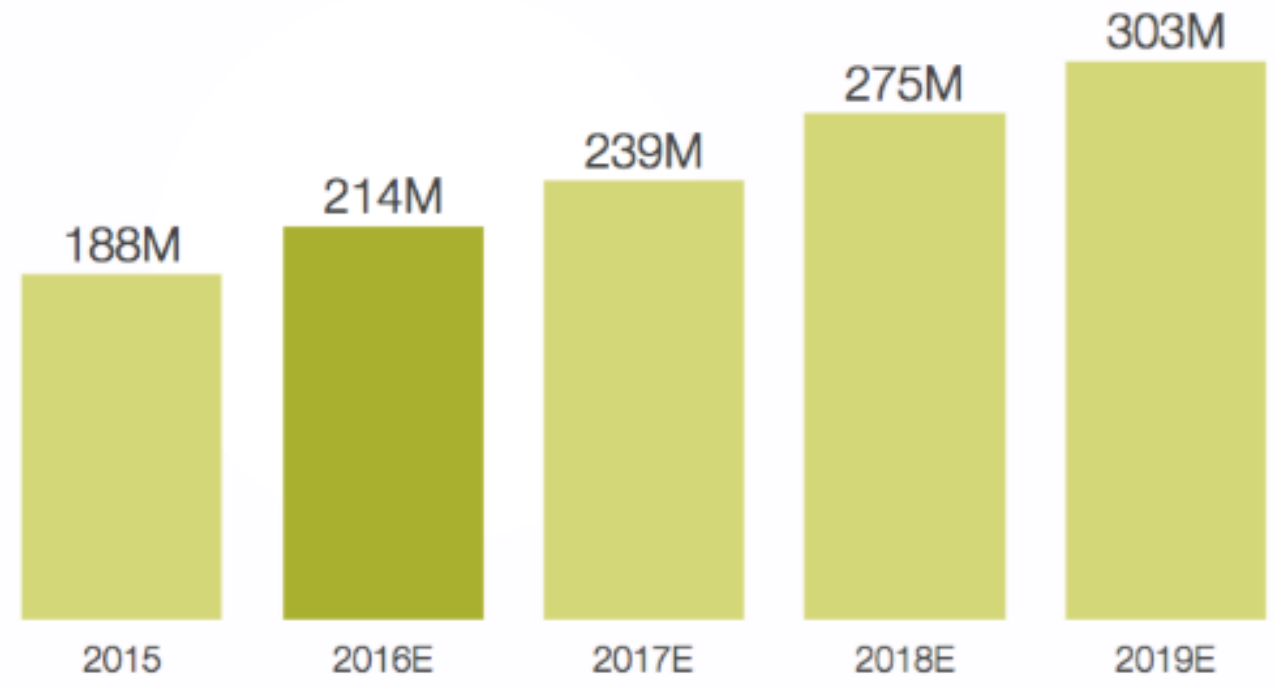

Fonte: Superdata Research, 2016

Atualmente no Brasil, os canais pagos Sportv e ESPN já possuem em suas grades espaços dedicados aos e-sports, com transmissões de jogos dos principais campeonatos, assim como programas de discussão sobre a atividade no Brasil e no mundo. Além disto, há campanhas que buscam o reconhecimento dos e-sports como esporte pelo público, como se observa na Figura 1, que ilustra a campanha promovida pela ESPN, tanto na televisão quanto na sua página da rede social Facebook, dedicada aos e-sports (ESPN Games).

Figura 1 - Imagens de campanha de divulgação dos e-sports da ESPN
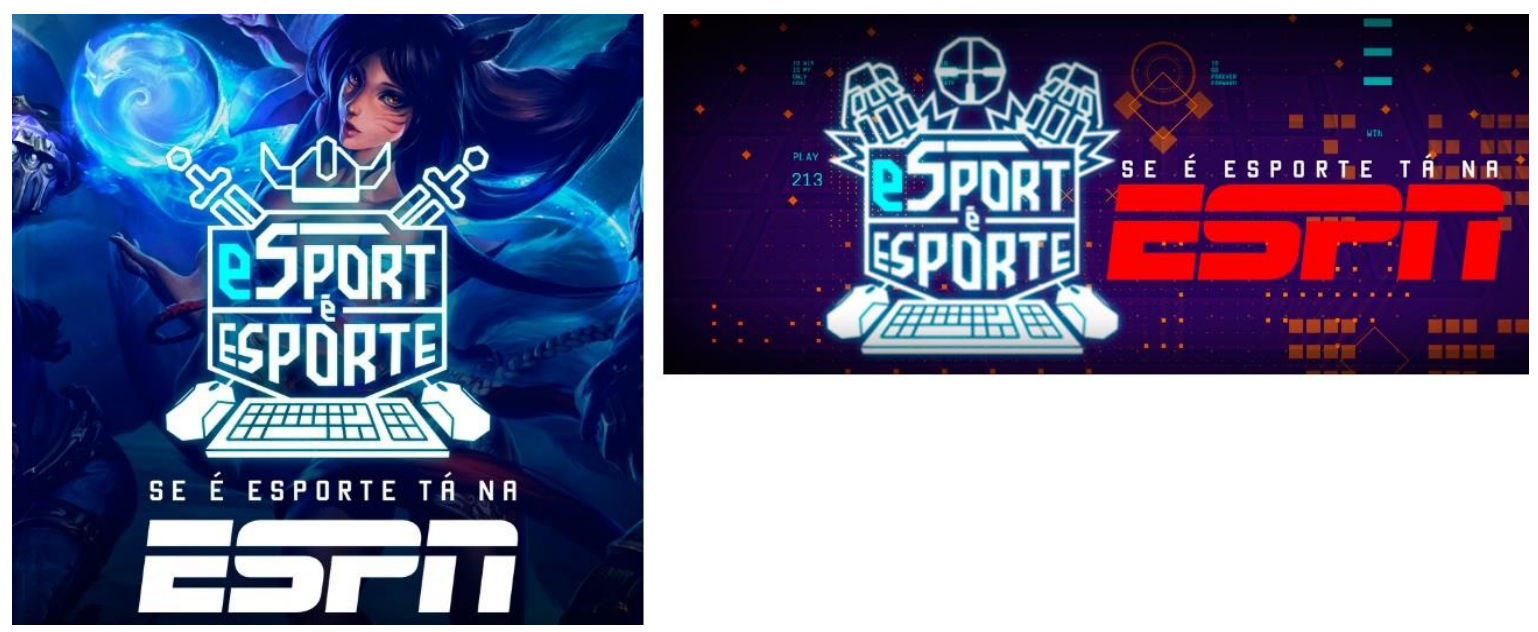

Fonte: Facebook ESPN Games 
Esse trabalho buscará identificar as principais barreiras ao reconhecimento e crescimento dos e-sports como uma modalidade esportiva, apesar de seu elevado potencial.

\subsubsection{Destaques no mundo}

O mercado de e-sports vem atraindo investimentos de grandes empresas, como são os casos das gigantes de telecomunicações coreanas KT Telecom e SK Telecom, que possuem times atuando sob seus nomes, assim como de clubes de outros esportes, como o clube de futebol Paris Saint Germain que adquiriu uma Equipe de LOL - League of Legends (um dos mais populares esportes eletrônicos da atualidade, que conta com mais de 100 milhões de jogadores no mundo de acordo com sua produtora, a Riot Games), que passou a atuar sob a bandeira do clube.

No Brasil, há também exemplos de clubes de futebol a se envolverem com os e-sports. O clube do Remo realizou uma parceria com a Brave E-sports, formando assim a Remo Brave E-sports, atualmente encerrada. O clube do Flamengo, em novembro de 2017, realizou uma seleção de jogadores para a formação de dois times de League of Legends que atuassem sob a sua bandeira: um time principal e um time de base para desenvolvimento de novos pro-players (jogadores profissionais).

Alguns atletas profissionais também investem nos e-sports, como o jogador americano de basquete Shaquille O'Neal e o ex-jogador de futebol brasileiro Ronaldo "Fenômeno" que, com um sócio, adquiriu $50 \%$ da equipe CNB E-sports, a fim de popularizar a atividade e potencializar seu investimento.

Além desses casos, há notícias de que mais clubes de futebol estão interessados na atividade de e-sports, como é o caso de times da primeira divisão de futebol alemã, além de equipes da NBA (liga de basquetebol americana) que acompanham o desenvolvimento do mercado com vistas a entrada em um futuro próximo.

\subsubsection{Reconhecimento do e-sport no Brasil}

Apesar de todo seu crescimento e visibilidade mundial, no Brasil os esports ainda não são reconhecidos como um esporte. Segundo aqueles que não o reconhecem, diferentemente de esportes tradicionais como futebol, vôlei e 
basquete, as dimensões físicas, psicológicas e motoras dos atletas não são tão relevantes.

Praticantes, atletas e profissionais de e-sports muitas vezes são recriminados e sofrem com julgamentos acerca de suas vidas pessoais e profissionais por participarem da atividade, como se observa na figura 2, quando, enquanto o comentarista Gustavo "Gstv" Cima comenta uma partida de League of Legends no canal pago Sportv, uma personalidade relativamente conhecida o critica por usar um terno ao comentar o jogo.

Essa falta de reconhecimento e o preconceito por parte de um segmento da população com os e-sports são importantes barreiras ao desenvolvimento da atividade.

Figura 2 - Comentário discriminatório sobre transmissão de e-sport
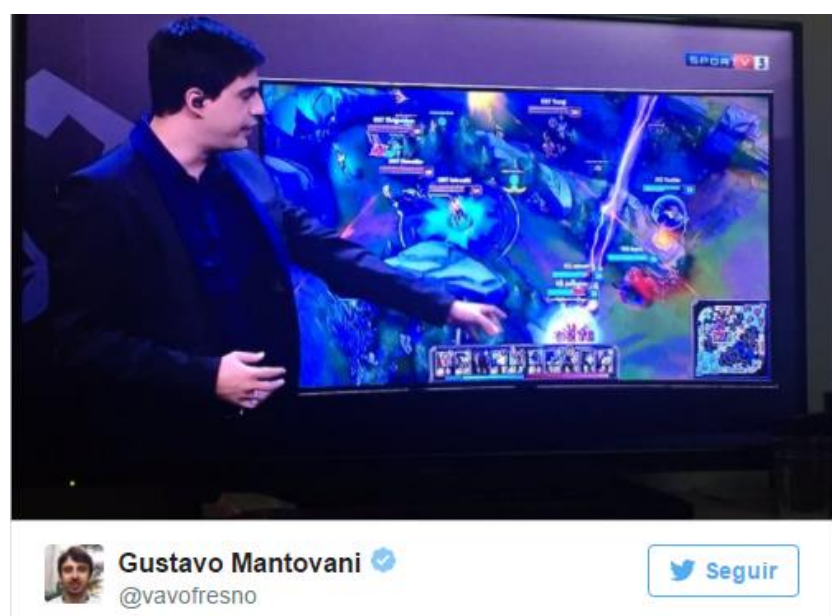

Pesquisa: o quão vocês conseguem levar a sério um cara de terno comentando videogame na TV?

21: 46 - 18 Feb 2017

Fonte: Twitter

\subsection{Questão do estudo}

Este trabalho busca responder à questão: Quais as principais barreiras ao desenvolvimento dos e-sports na indústria do entretenimento no Brasil e como superá-las?

\subsection{Objetivo Final}

O objetivo final deste estudo é identificar as principais barreiras existentes que limitam o desenvolvimento do mercado de e-sports no Brasil e como elas poderiam ser superadas pelas organizações atuantes no segmento. 


\subsection{Objetivos intermediários}

Para alcançar o objetivo final, os seguintes objetivos intermediários deverão ser atingidos:

- Identificar os interesses das organizações esportivas nos e-sports.

- Identificar as barreiras enfrentadas para o desenvolvimento do mercado de e-sports no Brasil.

- Identificar os tipos de discriminação enfrentados pelos envolvidos em e-sports.

- Mapear alternativas de superação das barreiras de entrada para as organizações atuantes e interessadas em atuar no segmento.

\subsection{Delimitação e foco do estudo}

Este estudo fará uma abordagem do ponto de vista dos participantes das organizações, empresas e profissionais atuantes no segmento de e-sports no Brasil no ano de 2017.

\subsection{Relevância}

O estudo é relevante para as empresas atuantes no segmento de e-sports que buscam o desenvolvimento da atividade no Brasil, assim como outras indústrias emergentes locais. 


\section{Referencial Teórico}

\subsection{0 e-sport}

O site Dictionary.com define a palavra "e-sports" como "torneios competitivos de vídeo games, especialmente entre jogadores profissionais.". A origem da palavra se dá com a junção do "e" (eletrônicos) com "sports" (esportes).

As competições de e-sports são organizadas de maneira semelhante às competições dos esportes mais conhecidos, com times e atletas disputando entre si, representando sua organização ou nação. As competições são realizadas em estúdios, ginásios ou estádios, com ou sem a presença de torcidas, transmissão televisiva ou via stream (online através das plataformas de vídeo).

Entre os e-sports, quatro podem ser tratados com maior destaque: o League of Legends (LOL), Counter Strike: Global Ofensive (CS:GO), Dota 2 e Overwatch.

- "Em League of Legends, os jogadores assumem o papel de "invocadores", controlando campeões com habilidades únicas e que lutam com seu time contra outros invocadores ou campeões controlados pelo computador. No modo mais popular do jogo, o objetivo de cada time é destruir o nexus da equipe adversária, uma construção localizada na base e protegida por outras estruturas. Cada jogo de League of Legends é distinto, pois os campeões sempre começam fracos e progridem através da acumulação de ouro e da experiência ao longo da partida." (Fonte: Wikipédia)

- "Counter-Strike (usualmente abreviado como CS) é uma série de jogos eletrônicos de tiro em primeira pessoa multiplayer, no qual times de terroristas e contra terroristas batalham entre si, respectivamente, realizando um ato de terror (explodindo bombas, fazendo reféns) e prevenindo-os (desarmando bombas, resgatando reféns)." (Fonte: Wikipédia)

- Dota 2 "é baseado em partidas online e off-line, com o objetivo primário de cada partida sendo derrotar a equipe adversária, 
destruindo o "ancião" que se localiza no centro da base inimiga. Cada base é defendida por torres e ondas de unidades (chamadas de criaturas) que percorrem os caminhos principais do mapa (chamadas de trilhas) que levam à suas bases." (Fonte: Wikipédia)

- "Overwatch possui um combate de equipe com dois times rivais compostos de seis jogadores cada. Os jogadores podem escolher um de vários heróis, cada qual com suas próprias habilidades únicas e função de classe." (Fonte: Wikipédia)

Segundo Alan "Nahaz" Bester, um estatístico e analista de Dota 2, 0 League of Legends, que possui campeonatos em várias regiões do mundo, é o "único e-sport que se assemelha às instituições esportivas tradicionais, tendo temporadas competitivas agendadas, restrições obrigatórias sobre negociações com jogadores e regras para a venda de franquias e equipes, entre outros".

Nos e-sports há diversos atores que fazem parte da comunidade e do cenário competitivo:

- Os jogadores (players)

- Os comentaristas e analistas

- As equipes profissionais de suporte aos jogadores, como: técnicos, fisioterapeutas, nutricionistas, psicólogos.

- Os streamers, pessoas que transmitem suas partidas pela internet (através do Youtube ou Twitch Tv)

- Os produtores de conteúdo de áudio e visuais

- Os jogadores amadores

- Os torcedores

\subsection{Esporte}

Como define o dicionário, "esporte é: a prática metódica, individual ou coletiva, de jogo ou qualquer atividade que demande exercício físico e destreza, com fins de recreação, manutenção do condicionamento corporal e da saúde e/ou competição."

Embora esse trabalho compare os e-sports com os esportes tradicionais, seu foco está na discussão das barreiras ao desenvolvimento desta nova modalidade como uma indústria no país. 


\subsection{Indústrias emergentes}

"Indústrias emergentes são indústrias recentemente formadas, ou reformadas, criadas por inovações tecnológicas, alterações nas relações de custos relativos, surgimento de novas necessidades dos consumidores, ou outras alterações econômicas e sociais que elevam um novo produto ou serviço em nível de uma oportunidade potencialmente viável de negócio (PORTER, 2004, p.223)".

O e-sport ainda vem sendo impulsionado pelo desenvolvimento, tanto da indústria de jogos eletrônicos, como pelos novos meios de comunicação pela internet, que permitem a interação entre atletas e torcedores, tal como a transmissão e disputas pela rede de torneios amadores, semiprofissionais e profissionais que aumentam a visibilidade e a promoção de eventos do segmento.

\subsubsection{Estratégias competitivas em indústrias emergentes}

De acordo com Porter (2004, p. 223), "a característica essencial de uma indústria emergente, do ponto de vista da formulação de estratégia, é que não existem regras nesse jogo. O problema competitivo nesse tipo de indústria é que todas as regras devem ser estabelecidas de modo que a empresa possa competir e prosperar sujeita a elas. A ausência de regras é ao mesmo tempo um risco e uma fonte de oportunidade; de qualquer modo, isso tem de ser controlado".

Segundo Porter (2004, p. 241), "em indústrias emergentes as empresas devem buscar construir uma boa imagem e reputação e ganhar a lealdade dos clientes. Por este motivo, uma entrada rápida no segmento, para busca de aprendizagem e ganhos de escala costumam ser elementos que se associam ao sucesso das empresas."

Os e-sports são meios de entretenimento que estão buscando seu espaço no meio de esportes maiores e já estabelecidos por todo o mundo, como futebol, vôlei e basquete, que tendem a reagir ao avanço da nova modalidade, na busca de ocupação do espaço competitivo, seja na transmissão em plataformas online e televisivas, seja com o tempo que as pessoas possuem para assistir as transmissões. 


\subsubsection{Problemas que restringem o desenvolvimento das indústrias emergentes}

"Indústrias emergentes enfrentam limitações ou problemas, de diversos graus de gravidade, ao realizarem a sua arrancada inicial. Isso provém do caráter novo da indústria, de sua dependência para o crescimento de outras entidades econômicas externas e de exterioridades em seu desenvolvimento resultantes de sua necessidade de induzir os compradores a fazer uma substituição pelo seu produto (PORTER, 2004, p. 229)".

No geral, para a prática dos e-sports são necessários alguns itens básicos. Assim como os tênis e chuteiras do basquete e futebol, nos e-sports são necessários componentes de hardware (computador, mouse, teclado e monitor) e conexão à internet. Alguns desses itens podem ser de diversos tipos e modelos, de melhor ou pior qualidade, assim como em outros esportes. Além disto, para a evolução dos e-sports, são de importância fundamental o desenvolvimento das plataformas de transmissão online, a melhoria das conexões de internet e a sua difusão pela "TV aberta", que são os canais em que maior parcela da população tem acesso devido ao seu valor reduzido em comparação com o valor pago para as operadoras de televisão a cabo, que transmitem canais de conteúdos mais específicos, entre outros.

\subsubsection{Ausência de infraestrutura}

"Indústrias emergentes enfrentam frequentemente dificuldades como as de fornecimento de materiais, causadas pela inexistência de uma infraestrutura adequada (PORTER, 2004, p. 230)".

No caso dos e-sports, um exemplo de infraestrutura importante deficiente no Brasil é a conexão de internet, que ainda apresenta pontos sem acesso ou com baixa qualidade em termos de velocidade de conexão banda larga, como demonstra o Gráfico 3, o que limita o acesso, tanto de expectadores às transmissões dos torneios, como o desenvolvimento de novos players (atletas). 


\section{Gráfico 3 - Faixa de velocidade de conexão banda larga em cada cidade do Brasil}

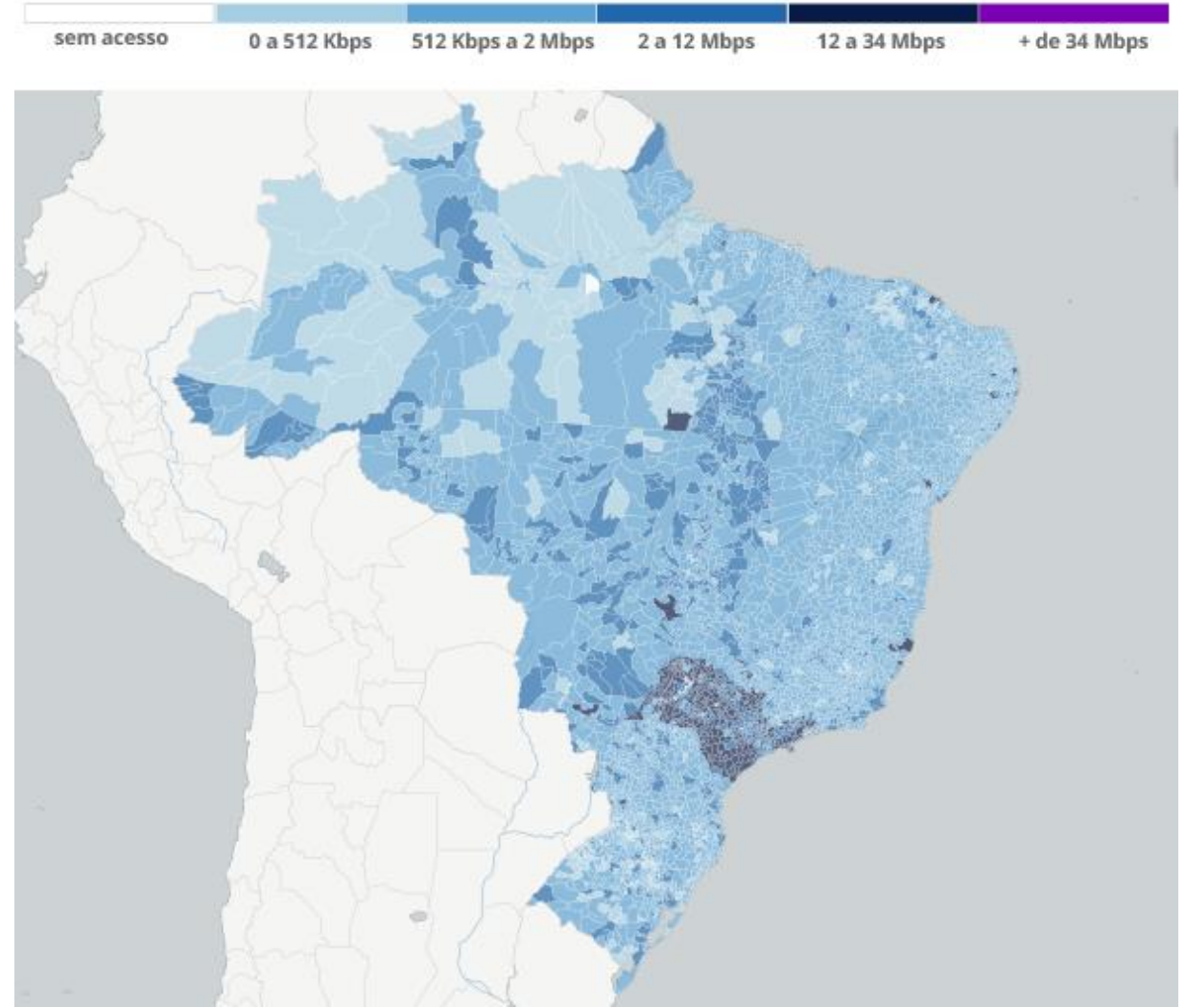

Fonte: Anatel, 2015

\subsubsection{Mercados iniciais e posteriores}

"Uma das questões cruciais para propósitos estratégicos em uma indústria emergente é, com frequência, a avaliação dos mercados que se abrirão mais cedo para o produto da nova indústria e aqueles que se abrirão mais tarde. Essa avaliação não apenas ajuda a enfocar o desenvolvimento do produto e os esforços de marketing como é também essencial para a previsão da evolução estrutural, uma vez que os mercados iniciais frequentemente exercem uma grande influência na maneira como uma indústria se desenvolve. Mercados, segmentos de mercado e mesmo determinados compradores dentro desses segmentos podem ter uma receptividade bastante diferente em relação a um novo produto (PORTER, 2004, p. 234)".

No Brasil, o desenvolvimento dos e-sports encontra-se bastante aquém dos países da América do Norte, Europa e Ásia. Um dos objetivos do presente trabalho é descobrir as razões que tornam esse desenvolvimento mais lento no Brasil em comparação com os países das regiões citadas. 


\subsubsection{Escolhas estratégicas}

"A fase emergente do desenvolvimento de uma indústria é provavelmente o período em que os graus estratégicos de liberdade são os maiores e em que a vantagem de boas escolhas estratégicas é a mais alta possível na determinação do desempenho (PORTER, 2004, p. 238)".

Os e-sports no Brasil encontram-se nesse momento "emergente" do desenvolvimento, e, por isso, este trabalho é relevante, ao ter como objetivo identificar barreiras e sugerir ações apropriadas para superá-las.

\subsubsection{Exterioridades no desenvolvimento das indústrias}

“Em uma indústria emergente, um tópico estratégico chave é o equilíbrio que a empresa tenta conseguir entre a defesa da indústria e a busca de seus próprios interesses. Por causa de possíveis problemas quanto à imagem da indústria, à credibilidade e à confusão dos compradores, na fase emergente a empresa depende, em parte, das outras na indústria para o seu próprio sucesso (PORTER, 2004, p. 238)".

A imagem da indústria dos e-sports é afetada negativamente por aqueles que apenas o enxergam como "joguinhos de vídeo game" o que demanda atenção para a defesa da sua imagem, e que acaba exigindo tempo e outros recursos que poderiam estar sendo destinados à busca dos interesses da indústria, como o aumento do número de expectadores, captação de patrocinadores ou outros interesses.

\subsubsection{Mudança de papel dos canais}

"Estrategicamente, a empresa em uma indústria emergente tem de estar preparada para uma possível mudança na orientação de seus fornecedores e canais de distribuição à medida que cresce e se afirma. Os canais de distribuição podem se tornar mais receptivos a investir em instalações, publicidade e assim por diante em colaboração com as empresas. Uma exploração antecipada dessas mudanças de orientação pode dar à empresa uma vantagem estratégica (PORTER, 2004, p. 240)".

No processo de desenvolvimento da indústria de e-sports, alguns parceiros já se fazem importantes por meio de suas colaborações e investimentos na indústria. Entre eles estão alguns canais esportivos que já abrem espaço em suas grades para a transmissão dos eventos de e-sports, assim como para a 
divulgação na mídia acerca do que são e-sports, e empresas fornecedoras de material esportivo e patrocinadores.

\subsubsection{Oportunidades de entrada}

“Uma decisão estratégica crucial para a concorrência em indústrias emergentes é a oportunidade adequada da entrada. Uma entrada prematura (ou pioneirismo) envolve risco elevado, mas pode envolver também barreiras de entrada menores e pode proporcionar um grande retorno (PORTER, 2004, p. 241)".

Como no Brasil o mercado de e-sports ainda se encontra pouco desenvolvido em comparação aos outros países, as barreiras que as empresas e equipes esportivas possuem para entrar ainda não são tão elevadas, o que deve aumentar as chances de ocorrer um crescimento da presença de times famosos em esportes já consolidados (como o futebol) no cenário de e-sports no Brasil.

\subsection{Substituição como meio de entretenimento}

"A substituição é o processo pelo qual um produto ou um serviço suplanta outro ao desempenhar uma função ou funções particulares para um comprador" (PORTER, 1989, p. 251).

Os e-sports são eventos de esportes eletrônicos que contam com presença de público na torcida, possuem presença nas transmissões esportivas na televisão ou outros meios de transmissão. Assim, o desenvolvimento do mercado de e-sports afeta outros esportes que também lutam por seu espaço no gosto, disponibilidade de tempo e recursos dos torcedores e patrocinadores, assim como outras alternativas de entretenimento para as pessoas.

\subsubsection{Identificação de substitutos}

"A identificação de substitutos exige a busca de produtos ou serviços que desempenhem a mesma ou as mesmas funções do produto de uma indústria e não de produtos que têm a mesma forma (PORTER, 1989, p. 252)".

Tanto os esportes tradicionais como os e-sports desempenham a função de entretenimento esportivo para os expectadores. O Gráfico 4 ilustra o perfil dos jogadores, o que indica os segmentos etários em que a substituição poderá ser mais acentuada. 


\section{Gráfico 4 - Perfil do jogador (idade)}

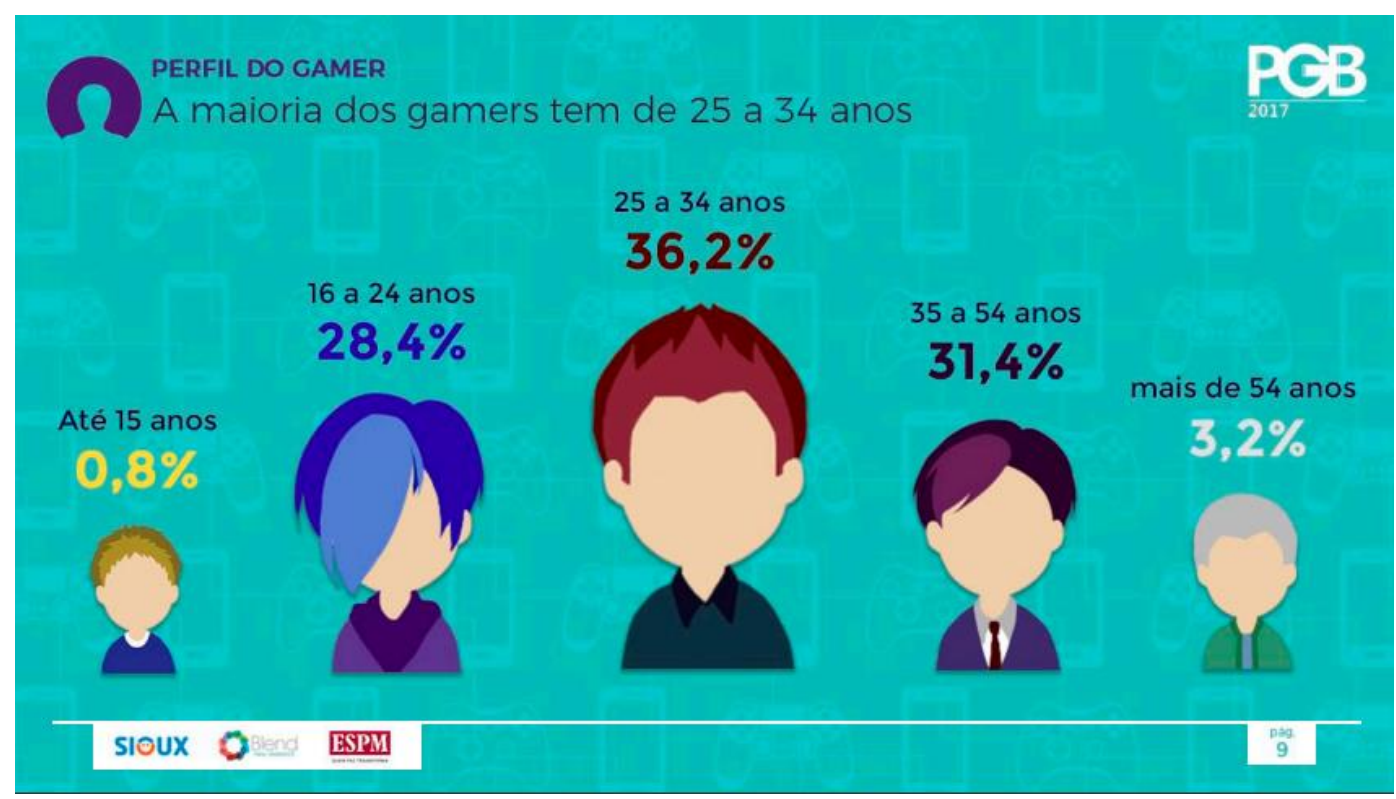

Fonte: Pesquisa Game Brasil, 2017

\subsubsection{Mudança na percepção de valor do comprador}

"A percepção de valor pelos compradores modifica-se amiúde no decorrer do tempo na substituição, porque o tempo e a atividade de marketing estão trabalhando para alterar o modo como os compradores veem um substituto em relação a um produto. Um substituto pode ganhar um valor percebido no decorrer do tempo à medida que os compradores vão se familiarizando cada vez mais com o seu uso" (PORTER, 1989, p. 270).

Com o passar do tempo e com o desenvolvimento dos e-sports, sua imagem tem mudado, passando eles a serem cada vez mais aceitos pelo público e aos poucos cada vez mais reconhecido como uma prática esportiva. Isso tem sido relatado por atletas e profissionais da área, que, por serem muito jovens, disseram ter tido dificuldades para conseguirem a aceitação dos pais quando contaram qual rumo profissional que estavam seguindo, mas, com o passar do tempo, esses pais perceberam que de fato existe uma profissionalização da atividade, mudando sua percepção inicial. 


\section{Metodologia}

\subsection{Tipo de pesquisa}

\subsubsection{Quanto aos fins}

A pesquisa deste estudo é descritiva, apoiando-se principalmente em dados da imprensa comercial sobre o League of Legends, que "é a única liga que se assemelha às instituições esportivas tradicionais, apresentando temporadas competitivas agendadas, restrições obrigatórias sobre negociações com jogadores, regras para a venda de franquias/equipes, entre outros" (BESTER, 2017). Além disto, o League of Legends possui uma base maior de jogadores do que os demais. De acordo com a sua produtora, a Riot Games, o LOL - League of Legends conta com mais de 100 milhões de jogadores no mundo.

\subsubsection{Quanto aos meios}

Por se tratar de um tema com desenvolvimento recente, esse estudo teve como principal referência conceitual os conceitos de Porter $(1989,2004)$ sobre indústrias emergentes, reportagens veiculadas em plataformas online sobre esports, e uma pesquisa de campo composta por entrevistas com alguns dos principais agentes do meio.

\subsection{Universo e amostra}

O universo da pesquisa foi composto por diferentes agentes atuantes nos e-sports no Brasil. A pesquisa empregou um questionário utilizado na amostra, composta por dois streamers, dois atletas, um repórter e um produtor de conteúdo. O questionário teve como objetivo buscar a percepção acerca das principais barreiras que afetam o desenvolvimento dos e-sports no Brasil de acordo com as perspectivas dos respondentes. 


\subsection{Seleção da amostra}

A escolha dos entrevistados foi realizada de forma a obter a maior amplitude de perspectivas dentro do cenário dos e-sports no Brasil, de forma a obter diversas opiniões acerca das barreiras enfrentadas para 0 desenvolvimento da atividade no país.

A seleção foi feita de forma não probabilística, e por conveniência, uma vez que o acesso aos contatos pelo entrevistador foi um critério importante, tal como a experiência e vivência dos sujeitos no mercado de e-sports no Brasil. Os entrevistados foram:

- Felipe "Flip" Neves - produtor de conteúdo musical do League of Legends

- Ana Carolina Vieira de Oliveira "Tawna" - repórter do League News (programa de reportagens sobre League of Legends)

- Guilherme "Guizão" Motta - streamer do League of Legends

- Gabriel "Turtle" Peixoto - jogador profissional de League of Legends

- Victor "Sier" Reis - aspirante a jogador profissional de League of Legends

- Arlindo "Element" Neto - streamer do League of Legends

\subsection{0 procedimento de coleta de dados}

A coleta de dados foi realizada por meio de entrevistas individuais. As entrevistas foram realizadas de forma presencial, por e-mail e por programas de comunicação via computador, com gravação de áudio no caso das entrevistas presenciais e por programas de comunicação, sempre após a autorização dos entrevistados.

\subsection{Tratamento de dados}

Após a coleta das entrevistas, quatro das quais gravadas, elas foram transcritas e reunidas às outras duas, que já haviam sido feitas por e-mail ou rede social, em uma tabela onde as respostas de cada questão estavam organizadas lado a lado para facilitar a análise qualitativa do conteúdo. Em seguida, foram buscadas associações entre as respostas dos entrevistados com as teorias descritas no referencial teórico. 


\subsection{Limitações do método}

Os métodos escolhidos para a realização do trabalho (entrevistas e análise qualitativa dos dados) apesar de capazes de proporcionarem uma visão ampla do objeto estudado (GIL, 2007), possuem limitações, como a influência do entrevistador sobre o entrevistado. Outra limitação associa-se à dificuldade de se manter uma neutralidade na etapa da análise dos resultados obtidos na coleta dos dados, o que pode influenciar a fidelidade ao evento real sendo analisado. 


\section{Apresentação e análise dos resultados}

Este capítulo está organizado em cinco seções que apresentam e discutem os principais resultados alcançados, assim como suas implicações em relação aos objetivos da pesquisa.

\subsection{O e-sport}

Com base na pesquisa qualitativa, pode-se observar que, para os agentes do cenário de e-sports no Brasil que foram entrevistados, o e-sport é como um esporte qualquer, pois eles enxergam que o que torna uma atividade em um esporte é a dedicação, disciplina e competitividade. Esses fatores são encontrados nos e-sports, pois eles demandam várias horas de treinamento, com disciplina acerca dos horários de treinamentos com seu respectivo time, e com todos os times buscando cada vez mais se aperfeiçoarem, gerando uma competitividade, similar ao de outros esportes.

"O e-sport para mim é como se fosse um esporte comum tradicional, como se fosse futebol, vôlei ou basquete, só que voltado para o mundo eletrônico, no caso computador, ou até mesmo videogame. Têm campeonatos de FIFA, League of Legends, Counter Strike, tem vários jogos que já existem campeonatos, então acho que isso também é um esporte, porque você se dedica o mesmo tanto que os outros atletas de um esporte convencional. E todo mundo quer ser o melhor, então isso acaba motivando cada pessoa, cada jogador a sempre ser melhor e gera essa competitividade, então isso que é o e-sport para mim". (Gabriel "Turtle" Peixoto - jogador profissional de League of Legends).

A citação anterior evidencia a visão desse "pro player" que em períodos de competição revelou que seus treinos chegam a ultrapassar dez horas diárias dentro das Game Houses (GH) - que são centros de treinamentos comuns no nível profissional dos esportes eletrônicos, onde os jogadores vivem todos juntos no mesmo local, que além de ser uma moradia, também possui espaço dedicado 
para os treinamentos. Tal convívio próximo e a intensidade nos períodos de treinamento geram desgastes físicos e psicológicos, assim como podem gerar estresses decorrentes da convivência diária com companheiros de equipe e os membros da comissão técnica.

Como define o site Dictionary.com, a palavra "esport" significa: "torneios competitivos de vídeo games, especialmente entre jogadores profissionais.". E sua origem se dá da junção do "e" (eletrônicos) com "sports" (esportes).

"O e-sport é basicamente o esporte eletrônico, é o esporte que você joga através do computador e que é como se fosse qualquer outro esporte" (Ana Carolina Vieira de Oliveira "Tawna" repórter do League News).

Os e-sports são formas eletrônicas de competir com os adversários em plataformas online em que existe a interação dos competidores, onde cada um põe à prova, contra um adversário, as suas estratégias e habilidades que são treinadas exaustivamente, além, claro, do seu talento e aptidão natural.

\subsection{Preconceito no e-sport}

Qualquer semelhança dos e-sports com os esportes já reconhecidos há muitos anos pode não ser mera coincidência. Possivelmente, a diferença está na aceitação mais ampla da população que ainda não conhece esse meio tão profundamente, e por isso ainda tem esse preconceito.

"Massivamente falando, sim, cara tem muito preconceito de maneira massiva. Tem gente que ainda debocha e ri, e diz que não é esporte, porque se você não faz exercício físico, você não está correndo atrás de uma bola, você não está brigando com ninguém, não é esporte." (Felipe "Flip" Neves - produtor de conteúdo musical de League of Legends).

Segundo Porter (2004), "Uma das questões cruciais para propósitos estratégicos em uma indústria emergente é, com frequência, a avaliação dos mercados que se abrirão mais cedo para o produto da nova indústria e aqueles que se abrirão mais tarde. Essa avaliação não apenas ajuda a enfocar o desenvolvimento do produto e os esforços de marketing como é também essencial para a previsão da evolução estrutural, uma vez que os mercados 
iniciais frequentemente exercem uma grande influência na maneira como uma indústria se desenvolve. Mercados, segmentos de mercado e mesmo determinados compradores dentro desses segmentos podem ter uma receptividade bastante diferente em relação a um novo produto".

Provavelmente, na sua origem, muitos dos não praticantes de futebol, vôlei ou basquete, podiam achar a disputa existente entre 22, 12 ou 10 pessoas por uma bola algo ridículo. Hoje em dia, os espectadores idolatram grandes personalidades dos esportes por suas demonstrações de habilidades e seus talentos únicos. Isso não é diferente para os torcedores dos e-sports.

"Vou usar o exemplo do Globo (globo.com) que é um site bastante visitado e conhecido. Toda notícia que eu abro, repito, toda notícia que eu abro, tem alguém falando que esporte eletrônico não é esporte, dizendo coisas tais como: "você nem precisa suar, como isso é esporte"? "Ficar gordo na frente do computador é esporte"? "Mexer os dedos é esporte"? Ser virgem é esporte"? Convenhamos que é ridículo tais comentários, você tem que ser um tanto quanto ignorante para comentar algo do tipo. Se for dessa forma, 11 pessoas correndo atrás de uma bola não é esporte, é diversão". (Guilherme "Guizão" Motta - streamer do League of Legends)

Com o passar dos anos, com a difusão desses esportes pela mídia, com a percepção deles como meio de entretenimento, como meio de interação da sociedade e como algo educativo, as pessoas foram percebendo que não se tratava apenas de vencer a disputa por uma bola, mas que se tratava também de uma forma de unir diversas pessoas independentemente da sua classe social, da sua cor, escolaridade ou de qualquer outra diferença individual. E assim como qualquer outro esporte, o e-sport possui seu papel social, seu papel disciplinador, seu papel interativo. Ele apenas ainda não foi difundido o suficiente para que a grande massa da sociedade veja isso. Segundo Porter (1989, p. 251), "a substituição é o processo pelo qual um produto ou um serviço suplanta outro ao desempenhar uma função ou funções particulares para um comprador". Talvez ainda mais do que em esportes tradicionais, nos e-sports todas as pessoas são aceitas, pois as diferenças de forma ou aptidão física dos praticantes não influenciam no seu desempenho dentro do campo de disputa online. 
"Hoje em dia depende de com quem você vai conversar sobre esporte eletrônico, mas a maioria acha engraçado e acha que é uma perca de tempo ridícula. Sofro um pouco de preconceito no meu prédio por isso por exemplo". (Arlindo "Element" Neto - streamer do League of Legends).

"Com certeza, eu acho que tem preconceito sim, eu acho que o Brasil é muito imaturo ainda, os adultos que tem, sei lá, mais de 40 anos, por exemplo, veem o e-sport como bobeira, do tipo "a é só um joguinho, isso não vai dar em nada, isso não vai dar futuro". É uma coisa que a nova geração está pegando agora, que a nova geração está vendo que é uma coisa séria, e creio que o esport vai crescer com essa nova geração. Essa geração mais velha, eles não vivenciaram isso, é difícil para eles acreditarem em algo que não fez parte do crescimento de vida deles, então eu creio que essa nova geração vai puxar o e-sport para cima. Eu tive muito problema com os meus pais né, eles nunca viram o e-sport, eles nunca viram o jogo que eu jogava como algo que fosse me dar futuro, então, por exemplo, quando eu quis ser jogadora profissional, eu mostrava pra eles, eu tentava convencer eles, eu tentava mostrar que era uma coisa que muita gente levava a sério, mas era difícil, foi muito difícil mostrar pros meus pais que era uma coisa levada a sério por muita gente." (Ana Carolina Vieira de Oliveira "Tawna" - repórter do League News)

Por serem desbravadores, os entrevistados ainda passam por momentos em que suas profissões são questionadas pelos seus familiares, amigos, pessoas próximas e até por pessoas que não gostam dos e-sports. Alguns questionamentos são mais intensos e chegam a provocar atritos, como por exemplo, na relação com familiares, enquanto que outros são mais amenos.

"Minha irmã mais velha sempre falava: "Você tem que fazer uma faculdade, um cursinho, você tem que fazer alguma coisa." $E$ os meus pais também falavam isso, aí quando eu comecei a receber dinheiro com isso, teve pagamento, salário, eles acabaram vendo que era um meio bom, um meio que estava crescendo, era uma coisa que eu gostava e eles começaram a apoiar $100 \%$ o que eu faço. Minha irmã mais velha pede desculpas até hoje praticamente, ela não queria ter interferido no meu sonho, só que eu entendo o ponto de vista dela, era uma 
coisa nova, ninguém sabia, e hoje em dia todo mundo me apoia, assiste meus jogos, me perguntam como que está indo, então é bom ter esse apoio da família quando você decide largar tudo para seguir o seu sonho. Se os pais apoiassem mais os filhos nesse meio seria muito bom. Já tem jogador hoje em dia que os pais não gostam do que ele faz e às vezes nem falam mais com o filho, ou vê o filho com outros olhos, e tem isso dentro do CBLOL, eu conheço pessoas que não tem relação boa com os pais, não só por causa disso, mas também afeta, então seria bom se todos os pais apoiassem nesse cenário novo." (Gabriel "Turtle" Peixoto jogador profissional de League of Legends)

Como tudo o que é novo, existe uma resistência até a aceitação, tendo que se lidar com críticas quanto ao seu modo de vida, sua profissão, etc. Os pioneiros costumam sofrer mais com essa resistência, sendo eles quem mostram os caminhos viáveis que existem. Como desbravadores, são os que assumem maiores riscos, porém as maiores recompensas os aguardam caso estejam certos, pois já estarão inseridos no meio quando ele tiver um "boom" de crescimento ou decrescimento.

\subsection{As barreiras enfrentadas pelos e-sports no Brasil}

\subsubsection{Barreiras econômicas}

Os e-sports são muito mais difundidos na América do Norte, Europa e Ásia, sendo esse continentes responsáveis por quase $98 \%$ da receita global restando aos outros continentes (incluindo a América do Sul) cerca de $2 \%$ desse faturamento global.

Durante as entrevistas, até mesmo os profissionais envolvidos com os esports no Brasil ficaram surpresos com esses números, pois sabiam que o segmento no Brasil estava muito defasado em relação às chamadas regiões majors (NA - North America, EU - Europa, e Ásia), mas não nesta dimensão.

"Eu acho que primeiramente eles levam mais a sério, eles investem mais, eles veem o e-sport como algo realmente sério. Vou fazer uma comparação do Brasil e essas regiões, eu acho que o Brasil ainda está muito imaturo na questão do e-sport, é uma coisa que está crescendo ainda, é uma coisa que não tem tanto investimento ainda, mas é uma coisa que está indo. Por 
exemplo, América do Norte, Europa e Ásia, os caras levam muito a sério. Eu acho que nesses países eles basicamente tratam $o$ jogo como se fosse algo mais sério mesmo, eles realmente investem, eles sabem que é uma parada séria, que isso tem retorno, que é uma coisa que tem muitos jogadores, existem muitos jogadores bons, muitos jogadores que querem competir, existe muito investimento, então eu acho que essas regiões tem uma visão um pouco mais amadurecida, elas vivem mais o que os outros países não vivem." (Ana Carolina Vieira de Oliveira "Tawna" - repórter do League News)

"Cada vez que os anos passam fica maior e eu acho que $o$ e-sport só tem a crescer, não tem como ele acabar ou cair. Acho que só tem a crescer porque essa nova geração todo mundo joga, todo mundo conhece o meio eletrônico, então acho que seria bom se as empresas começassem a investir. O problema é que no Brasil ainda está tendo muita crise, não está tendo muito dinheiro circulando aqui no Brasil, então acho que isso acaba atrapalhando, ninguém quer investir muito, porque esse meio ainda é uma coisa nova, então você não tem como ter retorno tão facilmente assim tão rápido, é meio que um tiro no escuro, então acho que é por isso que muitas empresas do Brasil ainda não tão investindo." (Gabriel "Turtle" Peixoto - jogador profissional de League of Legends)

Aqui no Brasil as grandes empresas ainda não entraram nesse mundo, possivelmente por desacreditarem no potencial dos e-sports no Brasil, seja por questões culturais de que o Brasil ainda é visto como o país do futebol que é o que domina as discussões de bares, restaurantes, ruas e etc. Ou pode ser que o momento atual em que os e-sports no Brasil estão crescendo e se desenvolvendo seja ruim, pois a economia se encontra em dificuldades, que se vê bastante debilitada, com as grandes empresas (potenciais investidoras) cortando verbas que poderiam ser destinadas a patrocínios e investimentos em equipes próprias, como acontece em outros países em grande escala, como destaque a Coréia, com gigantes de telecomunicação que possuem times próprios.

"Acho que lá fora além de ter um pouco mais de tempo, principalmente na Ásia, onde o e-sport já acontece há muito 
tempo, desde Starcraft que a galera já acompanha, e já tipo, passa na TV, tem canais sobre Starcraft, agora tem do LOL também se não me engano, além de lá ter mais tempo, aqui no Brasil não tem tanto investimento, não tem muito dinheiro entrando nesse mundo, não tem muitas empresas grandes, tipo Adidas, Nike, até empresas de carro, enfim, essas empresas grandes não estão patrocinando tanto, investindo muito dinheiro no cenário do Brasil, por isso acho que ainda é pequeno, lá no NA, EU e Ásia tem muito investimento, mais gente assistindo, proporcionando mais visualizadores, e atraindo mais dinheiro também, então acho que é por isso que aqui no Brasil a gente tá bem atrás, porque a gente não tem tanto investimento assim." (Gabriel "Turtle" Peixoto - jogador profissional de League of Legends)

Além das limitações financeiras que a economia do país está impondo, as grandes empresas podem estar receosas em se tornarem pioneiras nesse mercado, afinal, existem riscos para os primeiros que entrarem no segmento, em especial ao investirem prematuramente.

Segundo Porter (2004, p. 241), “Uma entrada prematura é adequada quando: a imagem e a reputação da empresa são importantes para o comprador e a empresa pode desenvolver uma reputação melhor sendo pioneira; a entrada prematura pode iniciar o processo de aprendizagem em um negócio em que a curva de aprendizagem seja importante, a experiência seja difícil de imitar e não será anulada pelas gerações sucessivas de tecnologia; a lealdade do cliente será grande, de modo que os benefícios se acumularão para a empresa que vender para esse cliente em primeiro lugar; vantagens absolutas de custo podem ser ganhas pelo comprometimento antecipado dos suprimentos de matérias primas, canais de distribuição, etc. E a entrada antecipada é especialmente arriscada quando: a concorrência inicial e a segmentação de mercado são em bases diferentes das que serão importantes mais tarde no desenvolvimento da indústria. A empresa, portanto, acumula as qualificações erradas e pode vir a enfrentar custos elevados de mudança; os custos de abertura do mercado são grandes, incluindo coisas como esclarecimento ao consumidor, aprovações legais e pioneirismo tecnológico, e os benefícios da abertura do mercado não podem ser patenteados pela empresa; a concorrência inicial com empresas pequenas e recém-criadas será dispendiosa, mas essas empresas serão substituídas posteriormente por uma concorrência mais vigorosa; a evolução tecnológica tornará os investimentos iniciais obsoletos e permitirá que as 
empresas que entrem mais tarde tenham uma vantagem por disporem dos produtos e dos processos mais novos".

Aqui no Brasil, algumas empresas já possuem times atuantes há algum tempo, e assim, são conhecidas como times tradicionais, como por exemplo, a Pain Gaming que possui uma line-up (time) na primeira divisão do CBLOL (Campeonato Brasileiro de League of Legends) desde os primórdios do torneio e, assim, colhe os frutos de ter uma das maiores, se não a maior torcida do cenário dos e-sports no Brasil. Além do fator torcida, empresas já consolidadas no segmento possuem a vantagem de já terem bastante experiência acumulada em comparação às mais novas, e isso pode-se refletir nos resultados obtidos pelo time, tal como nas suas negociações com possíveis patrocinadores que se sentem mais confortáveis em investir a longo prazo nessas empresas por saberem que estas estão comprometidas com o cenário, participações em feiras de games como a BGS (Brasil Game Show) e outras fontes de divulgação e receita como, por exemplo, a venda de uniformes e souvenires para seus torcedores que possuem a tendência de serem maiores conforme os resultados das equipes destas empresas.

Mas ao mesmo tempo em que a entrada prematura tem seus benefícios, é mais custoso enfrentar as dificuldades iniciais de esclarecimento ao público e desenvolvimento do mercado. Logo, cabe a cada organização avaliar o quão vantajoso pode ser entrar antes ou depois e escolher o melhor momento para investir na atividade de acordo com seus objetivos.

\subsubsection{Esforço físico}

Quando se pensa em esportes, a mente faz uma associação a atividades físicas intensas, como correr, chutar, contato físico, ou outras ações que evidenciam o desgaste físico. Nos e-sports tais associações não ocorrem facilmente, o que gera diversas discussões sobre se eles podem ou não serem considerados esportes.

"A questão do esforço físico acho que é o principal (barreira para os e-sports serem considerados um esporte), é o primordial que acho que afeta todo mundo. Mas assim, o que gera muito preconceito num todo é mais pela questão das pessoas não entenderem, porque assim, rola um pagamento salarial, você tem o treinamento, assim, toda a funcionalidade, toda a parte estrutural do time ela existe como um time de qualquer outro esporte, só que 
assim, não tem essa difusão toda, não é algo que assim, a, fulano de tal hoje no treino jogou muito bem, não é igual futebol que fala que o técnico botou tais jogadores como titulares e tais como reservas, acho que no e-sport ter essa questão muito fechada do time é algo que interfere muito no time, na aceitação. O pessoal não consegue ver, essa questão do físico também, e de também associarem que computador, essa questão online é muito de intelectual, de nerd, as pessoas não se veem muito nisso, a massa não se vê tão dentro disso, tão inserida nisso, então é difícil para eles aceitarem essa questão." (Felipe "Flip" Neves - produtor de conteúdo musical de League of Legendas)

"Eu acho que a principal barreira (para atividade ser considerada um esporte) é que você precisa ficar sentado muitas horas e muitas pessoas veem isso como você não estar fazendo nada, como você estar fazendo algo que não é importante só porque você está jogando." (Victor "Sier" Reis - aspirante a jogador profissional de League of Legends)

Fica evidente que a atividade física ou a falta de intensas demonstrações físicas por parte dos "e-atletas" é uma barreira para que os e-sports sejam considerados esportes. Como define o dicionário, "esporte é: a prática metódica, individual ou coletiva, de jogo ou qualquer atividade que demande exercício físico e destreza, com fins de recreação, manutenção do condicionamento corporal e da saúde e/ou competição.". E dessa definição, não existe uma única dessas demandas que não seja minimamente atendida pelos e-sports.

"Eu acho que assim, eu não acho que não é considerado um esporte, eu não consigo enxergar o e-sport como algo que não seja esporte, porque você não tem esforço físico, mas tem esforço mental, é como se você jogasse xadrez, e o xadrez é considerado um esporte. Então você tá ali no xadrez, você tá pensando, você tem estratégias pra abater o inimigo, você tem que pensar, você tem que estudar, é basicamente o que acontece com o LOL, você tem que pensar, você tem que estudar, você tem esforço mental porque você fica várias horas jogando, você se sente cansado, você se sente exausto, tem jogador que treina 15 horas por dia. Então eu não consigo ver o League of Legends, CS ou outros jogos que são considerados e-sports fora disso, eu não consigo, por exemplo: olhar para o League of Legends e falar que não é um 
esporte, então é difícil responder essa pergunta, porque eu não vejo esses jogos como se não fossem esportes." (Ana Carolina Vieira de Oliveira "Tawna" - repórter do League News)

Assim, embora aparente não existir esforços físicos por parte dos participantes, toda a dedicação que os profissionais empregam nos treinos, demanda "exercício físico e destreza", e os e-sports também podem servir "como fins de recreação, manutenção do condicionamento corporal e da saúde e/ou competição."

\subsubsection{Barreiras demográficas e de infraestrutura}

Além das barreiras já citadas, no Brasil ainda existem algumas outras, e quando os entrevistados foram questionados acerca delas, todos concordaram que existem barreiras relacionadas à infraestrutura, o que é comum em indústrias emergentes. Segundo Porter (2004, p. 230), "indústrias emergentes enfrentam frequentemente dificuldades como as de fornecimento de materiais, causadas pela inexistência de uma infraestrutura adequada ". No Brasil existem problemas na banda larga disponível e alto custo dos hardwares (componentes físicos dos computadores, como monitor, placa mãe, placa de vídeo, HD e etc.) que limitam o acesso de parte da população brasileira aos e-sports.

"Eu acho que melhorar a infraestrutura das conexões banda larga precisa, até porque a internet aqui no Brasil é muito cara, então facilitaria muito o acesso das pessoas aos jogos." (Ana Carolina Vieira de Oliveira "Tawna" - repórter do League News)

"As internets na maioria das vezes atrapalham sim, às vezes a gente tem que ter nas Games Houses duas internets, para quando uma cair a gente já ter outra para poder jogar, e isso atrapalha um pouco." (Gabriel "Turtle" Peixoto - jogador profissional de League of Legends)

"A internet com certeza tem que melhorar no Brasil, todo mundo tem problema com queda durante os jogos, muito frequente isso acontecer, muita gente tem dificuldade inclusive para melhorar por conta disso porque atrapalha bastante." (Victor "Sier" Reis - aspirante a jogador profissional de League of Legends) 
Como se pode perceber a partir das respostas dos entrevistados, a barreira relacionada ao acesso à internet, seja ela por baixa qualidade dos serviços fornecidos em algumas regiões ou pelo alto custo da banda larga no Brasil, que é uma das mais caras do mundo, influencia muito negativamente o desenvolvimento do cenário dos e-sports no país, atrapalhando o treinamento dos pro-players que chegam a ter duas conexões diferentes nas Game Houses, já contando com a possibilidade de instabilidade ou falta de uma das conexões em algum momento. É ainda mais complicado para os jogadores que não são profissionais ainda e que ainda não possuem uma renda vinda dos e-sports e por isso possuem menos recursos para investir em conexões banda larga de maiores velocidades ou residem em regiões com conexões que oscilam muito, o que atrapalha seus treinamentos.

"Melhorar a banda larga do Brasil é extremamente necessário. É inadmissível ligar para sua operadora para reclamar da lentidão de internet e o atendente não saber nem o que é ping (velocidade com que a conexão de internet consegue enviar e receber de volta um conjunto de informações). Lamentável." (Guilherme "Guizão" Motta - streamer do League of Legends)

Como as transmissões ainda são assistidas pela maioria dos espectadores pela internet, as conexões de baixa velocidade e muito oscilantes prejudicam a experiência. Muitas vezes as transmissões travam, fazendo com que alguns desistam de assistir aos campeonatos, prejudicando a popularidade e a relação dos espectadores com os e-sports.

Os hardwares também são uma significativa barreira para o desenvolvimento dos e-sports no Brasil.

"Ele (computador de qualidade) precisa ser mais acessível para o maior número de pessoas. Por exemplo, para jogar futebol você só precisa de uma bola e dois gols. Porém, caso você queira ser um profissional de LOL, você precisa investir no mínimo $R \$$ 2.000 em um computador para que ele seja razoavelmente aceitável para jogar, ter uma internet muito boa e ter noção de que a conta de luz vai vir bem alta. Tudo isso somado (computador para jogar, banda larga de qualidade e energia elétrica), já não é acessivel para todas as pessoas." (Guilherme "Guizão" Motta streamer do League of Legends) 
"Tem muita gente que não consegue jogar porque não tem computador, mas acompanha o cenário." (Gabriel "Turtle" Peixoto - jogador profissional de League of Legends)

É sabido que grande parte da população não possui acesso a computadores, a $11^{a}$ edição da pesquisa TIC Domicílios 2015 "mostra que a proporção de domicílios brasileiros com computador estabilizou em 50\%, o que representa 33,2 milhões de domicílios com acesso a computador. Na classe A, 99\% das pessoas têm computador em casa, na classe B, $84 \%$, na classe C, 47\% e nas classes D e E, 13\%". Além disto, uma grande parcela da população que possui computadores, não possui computadores com hardwares suficientemente capazes de executarem os jogos que são mais exigentes com as máquinas, como é o caso do League of Legends, do CS: GO e de outros títulos populares.

Sabendo disso, fica bastante perceptível o quanto o cenário deixa de crescer devido ao alto valor dos hardwares, já que grande parte da população pertencente às classes $\mathrm{C}, \mathrm{D}$ e $\mathrm{E}$ não tem oportunidade de participar do cenário, seja como jogador que apenas busca seu lazer, como espectador em busca de entretenimento, produtor de conteúdo ou até mesmo alguém que poderia vir a se tornar um jogador profissional.

\subsubsection{Mídia tendenciosa}

Além destas dificuldades, também foi citado que existem falhas na divulgação pela mídia que atualmente está presente em canais abertos, como a Globo, por exemplo, e em canais esportivos como Sportv e ESPN.

"Já passam algumas matérias. Ás vezes as entrevistas são tipo: "os meninos gastam o dia inteiro deles jogando" e tem que parar com esse olho de preconceito sabe, querendo mostrar esse lado ruim e nunca pegam o lado bom, nunca pegam o melhor lado nas entrevistas e isso é muito ruim para a gente desse meio. Com certeza (os canais são tendenciosos). Esse ano já está melhorando muito as entrevistas que eu vi ultimamente, mas no começo era só algo muito horrível, aí a gente ficava "caramba, não é assim que é", eles colocavam uma tendência tipo "não deixe seu filho ficar jogando o dia inteiro, porque isso prejudica", sempre traziam alguém que era especialista em problemas de vista por exemplo, eles traziam um médico dos olhos lá e ficava falando, e tipo, mano, não é esse o lado que a gente foca. Divulgação pela 
mídia é muito bom, com olhos mais claros, mostrando tudo o que tem de bom nesse meio." (Gabriel "Turtle" Peixoto - jogador profissional de League of Legends)

De acordo com essa citação, entende-se que as reportagens veiculadas sobre os e-sports, principalmente as menos recentes, foram reportagens feitas de formas tendenciosas. Essas reportagens foram feitas expondo riscos reais encontrados na prática intensa dos e-sports que assim como todos os esportes praticados de maneira intensa pode causar lesões aos jogadores, porém, raramente são encontradas reportagens que exponham os riscos de lesões desses esportes já tradicionais, e essa foi a crítica feita pelo jogador. Assim, os participantes acreditavam que a falta de interesse das mídias que produziam tais reportagens nos e-sports se devia ao seu maior interesse em esportes que lhe eram mais rentáveis.

\subsection{Formas de superação das barreiras}

Depois de listadas as principais barreiras encontradas no processo de pesquisa com os participantes da atividade, também foram enumeradas formas para superá-las.

"Inicialmente investir em publicidade televisiva, acho que seria um passo maneiro. Trocar ideia com algumas mídias de $t \mathrm{v}$ aberta, falar com programas de esporte, investir sim, pôr dinheiro para que isso seja transmitido e também gerar uma abertura." (Felipe "Flip" Neves - produtor de conteúdo musical de League of Legends)

"Eu acho que poderiam divulgar mais, fazer mais programas para conscientizar as famílias e mostrar o que é o e-sport e para mostrar que ele também tem um bom futuro, também tem uma boa renda e que não é algo que você vai fazer só por diversão, você vai ter que se esforçar, ter disciplina para conseguir chegar onde você quer, porque não é fácil... aquilo também é um trabalho." (Victor "Sier" Reis - aspirante a jogador profissional de League of Legends)

Segundo Porter (2004, p. 238), "em uma indústria emergente, um tópico estratégico chave é o equilíbrio que a empresa tenta conseguir entre a defesa da 
indústria e a busca de seus próprios interesses. Por causa de possíveis problemas quanto à imagem da indústria, à credibilidade e à confusão dos compradores, na fase emergente a empresa depende, em parte, das outras na indústria para o seu próprio sucesso." É nesse ponto onde as mídias televisivas se encontram como uma indústria importante para o desenvolvimento dos $e$ sports.

De uma forma geral, as sugestões foram bastante comuns, como o aumento do investimento nos e-sports, principalmente em mídias ainda pouco exploradas pela atividade, com foco nas televisivas, em especial as da televisão aberta que são acessíveis à maioria da população brasileira, que ajudariam a superar diversas das barreiras citadas, tanto com o investimento para transmissões dos campeonatos em canais abertos, para que o contato do público com os e-sports seja mais constante, quanto com o investimento em reportagens explicativas sobre os e-sports, de forma a desmistificar os jogos e torná-los mais aceitáveis para a população.

\subsubsection{Superando as barreiras econômicas}

"A procura das pessoas já está aumentando, a maioria dos jovens já joga alguma coisa, e a divulgação de que ser profissional nisso pode render um bom lucro também seria bom, também ter mais peneiras e empresas buscando mais atletas e também mais torneios profissionais. Não tem muito time profissional de LOL no Brasil, tem poucos times e acho que uma grande parte desse desenvolvimento depende dessas empresas virem e investirem." (Victor "Sier" Reis - aspirante a jogador profissional de League of Legends)

Do ponto de vista econômico, o investimento em reportagens e transmissão das partidas através das mídias televisivas, em especial as da televisão aberta, tal como o investimento em outros torneios além do CBLOL gerariam uma maior visibilidade de marca. Assim, se conseguiria um maior interesse das empresas para que venham a investir em times já atuantes na atividade sob a forma de patrocínio, apoio com o fornecimento de equipamentos e uniformes ou até mesmo a criação de novos times por parte das empresas de maior porte com interesse na divulgação de suas marcas, como as empresas atuantes nos segmentos de informática e eletrônicos, ou com grande interesse no público majoritariamente jovem ou de gamers. 


\subsubsection{Superando o preconceito}

Para melhorar a imagem dos e-sports, a divulgação em mídias televisivas (com reportagens, divulgação e transmissão de torneios, até mesmo criação de personagens em novelas que sejam gamers ou pro-players sem estereotipá-los assim como já foi feito com a criação de personagens que eram jogadores de futebol) também seria de grande importância para que esses se tornem mais conhecidos pela população, que passaria a reconhecer os pro-players como atletas e possíveis celebridades, assim como são reconhecidos os atletas dos esportes famosos no Brasil. Assim poderia ser superado o preconceito ainda existente acerca do perfil dos profissionais da área e até mesmo do esporte. Isso contribuiria para melhorar o cenário do e-sport no Brasil, já que, segundo Porter (1989, p. 270), "a percepção de valor pelos compradores modifica-se amiúde no decorrer do tempo na substituição, porque o tempo e a atividade de marketing estão trabalhando para alterar o modo como os compradores veem um substituto em relação a um produto. Um substituto pode ganhar um valor percebido no decorrer do tempo à medida que os compradores vão se familiarizando cada vez mais com o seu uso".

Como é um esporte muito psicológico como um todo, que requer muita atenção, você dificilmente pode abrir um treinamento para o público para que as pessoas possam assistir, para que as pessoas possam fotografar enquanto você treina. Então isso interfere bastante, mas só que isso também limita muito o pessoal, limita muito você poder pelo menos ver o time treinando ali, ver geral jogando junto, por mais tempo, tirar uma hora do treino para que as pessoas possam olhar, eu não sei como isso funcionaria, porque também é impossível você estar em um lugar jogando e nego gritando em volta, acho que falta mais dessa abertura do atleta com o público, até pra que um dia tipo: "eu sou a criança e quero jogar, e quero que o meu pai me apoie, eu poderia um dia ir ao treino de um time que eu sou fã e falar: pai é isso aqui, isso aqui é o time, esse cara tem essa função e esse aqui tem essa função. E isso eu acho interessante." (Felipe "Flip" Neves produtor de conteúdo musical de League of Legends)

Também seria importante aumentar a possibilidade de contato dos torcedores com os seus ídolos, o que já é feito em feiras sobre games como a BGS (Brasil Game Show), tal como o maior contato da população sobre o 
assunto com os profissionais, o que poderia ser intensificado criando centros de treinamento onde os torcedores pudessem assistir aos jogadores treinando sem que isso impactasse negativamente o rendimento destes nos treinos. Uma sugestão seria a criação de uma espécie de cúpula com isolamento acústico em locais movimentados, possivelmente em shoppings ou praças movimentadas, por curtos períodos de tempo, como um ou dois dias, em fases menos tensas de treinamento como em pré-temporadas, para que assim o público possa assistir e também ter um contato mais próximo com os seus ídolos.

\subsubsection{Superando as barreiras demográficas e de infraestrutura}

O investimento em mídias televisivas também ajudaria a tornar os e-sports mais conhecidos e acessíveis para a população que não possui computador em casa ou acesso à internet com qualidade suficiente para assistir através das plataformas online, desenvolvendo e aumentando o interesse do público e acelerando assim o crescimento dos e-sports no Brasil.

Quanto à barreira de infraestrutura das conexões de internet no Brasil, a indústria dos e-sports não possui ação direta, mas ela poderia influenciar indiretamente pela maior exigência dos seus praticantes diante das fornecedoras desse serviço, assim como efetuado pela indústria de computadores pessoais. De acordo com a matéria: "Jogos tiram do marasmo o setor de computadores" de Gustavo Brigatto ao Valor Econômico, "as empresas Acer, Dell, Samsung e outros fabricantes colocaram no mercado, desde o começo do ano passado, linhas de equipamentos desenvolvidos especialmente para atender as necessidades desse público (gamers)" Na mesma matéria, foi mencionado por Paulo Xu, fundador e presidente da DL, que este é "um mercado que cresce de $30 \%$ a $40 \%$ ao ano".

\subsubsection{Superando as barreiras da mídia tendenciosa}

É natural que o investimento inicial nas mídias televisivas dependeria de um possível aporte financeiro por parte das empresas já atuantes no segmento. Mas, com o tempo os canais abertos deveriam conseguir anunciantes suficientes para manter a programação dos e-sports nas suas grades sem a necessidade deste aporte financeiro das organizações envolvidas com a atividade, lucrando com os e-sports e o seu crescimento, e produzindo matérias favoráveis à sua prática, ao contrário das matérias negativamente tendenciosas veiculadas no 
passado. Evidentemente, sem deixar de lado sugestões para a prática mais segura e saudável dos e-sports, tendo como patrocinadores e anunciantes as empresas de equipamentos específicos para pessoas que passam muito tempo sentadas, jogando e treinando, como cadeiras, monitores, computadores e periféricos (mouse, mousepad, teclado, etc.).

\subsection{Interesse das organizações esportivas nos e-sports}

Como modalidade esportiva, é interessante para os e-sports que esses obtenham a adesão de clubes já consolidados para que seus torcedores tomem conhecimento dessa nova modalidade, aumentando assim a adesão do público. A partir do momento que determinado clube se destaque nessa modalidade, é normal que parte dos fãs comece a acompanhar as partidas mais importantes para torcer pelo seu clube independente da modalidade que esteja sendo disputada.

"Eu acho que as torcidas dos clubes esportivos torceriam também para os times do e-sport. Eu não acho que poderia ser visto de forma negativa, até porque, se a gente for pensar, no esporte tem várias modalidades, então o jogo eletrônico só iria ser mais uma, eu acho que, por exemplo, se tiver um clube que compre um time que joga esporte eletrônico, um clube famoso, vamos supor, eu acho que a galera ia torcer sim, ia torcer pelo time, porque a torcida torce pelo time, eu acho que tanto faz se troca o jogador, se o jogador muda de posição ou vai pra outro time, ele vibra pelo time, ele acompanha o time, então eu acho que isso seria bom e isso ajudaria também a ampliar o e-sport porque as torcidas dos outros esportes são torcidas grandes, então imagina que legal se os times de futebol comprassem os times de LOL, ia ser muito legal, então eu vejo isso como um ponto positivo." (Ana Carolina Vieira de Oliveira "Tawna" - repórter do League News)

O interesse da entrada dos clubes esportivos nos e-sports é recíproco.

"Seria muito bom se os times de futebol começassem a vir mais para os times de LOL porque eles têm bastante verba e eles conseguiriam investir bastante nas equipes, e como o cenário está no começo, você não gasta tanto assim, o valor que você deve 
gastar para montar um time de LOL é muito menor do que pra montar um time de futebol. Então não seria tanto gasto pra eles, $e$ se eles contratassem os jogadores certos, a staff certa $e$ montassem um time de ponta e eles fossem campeões e tudo mais, seria uma visão enorme pra eles, a galera do e-sport ia começar a gostar de um clube que é de futebol, e imagina os torcedores das duas modalidades torcerem pra um mesmo clube, acaba aumentando a torcida desse clube, então acho que seria bom sim se rolasse dos times de futebol partirem mais para o esport, talvez a galera do futebol ia falar: "po, isso ai não é esporte de verdade, isso ai são só meninos que não fazem nada em casa e só ficam jogando", mas ai é a galera mais antiga que não tem tanto a mente aberta, mas se um clube está investindo, então o cara não vai achar ruim o clube dele estar em outra modalidade, ainda mais se tiver ganhando, se tiver uma equipe boa, pra eles vai ser bom, então acho que seria bom pra todo mundo." (Gabriel "Turtle" Peixoto - jogador profissional de League of Legends)

Os grandes times de futebol, por exemplo, conseguiriam investir nos esports sem maiores dificuldades, pois já possuem toda uma estrutura de pessoal que cuida da gestão do clube. Eles teriam apenas que investir em estrutura, que poderia ser algo como está sendo proposto atualmente pelo time do Flamengo, com a criação de uma Game Office, onde diferentemente das Games Houses, os jogadores não morariam no mesmo local onde treinam, o que possivelmente reduziria os custos do investimento em uma equipe própria de e-sports e também diminuiria os atritos decorrentes da convivência intensa entre as pessoas. Além disso, por serem já conhecidos, já teriam uma grande base de torcedores capazes de gerar receitas com vendas de materiais esportivos e periféricos voltados para os e-sports, além de permitir o crescimento da sua base de torcedores pela adesão de pessoas que gostam de e-sports, mas que não possuem relação com clubes de futebol por não acompanharem a modalidade, e por alcançar um público infantil ainda sem clube definido, o mesmo impacto poderia ser verificado em outras modalidades esportivas, como o vôlei e o basquete.

"Eu vejo muito jogos de basquete do Flamengo, não curto muito basquete, mas por ser o meu time eu já torci muitas vezes e já assisti só pelo fato de ser o Flamengo. Se eu sou torcedor de um time e ele é bom em um esporte e agora ele começou a entrar 
em outro, eu vou me interessar em procurar e vou ficar interessado em saber o que é aquilo, porque o meu time está bem e está tentando conseguir alguma coisa, ainda mais se tiver tentando vencer os campeonatos ou alguma coisa assim. Inclusive o próprio Flamengo está criando um time de e-sports. Algumas pessoas podem sim achar irrelevante, mas eu imagino que a parte positiva vai ser muito mais pesada do que o pessoal que vai achar que é ruim e que vai ver o lado negativo, porque lado negativo não tem, é uma empresa que vai criar outro meio de competir e vai ter mais opções e jeitos de conseguir lucros, vai conseguir vender ingressos e investimentos com torneios, e vai ganhar torneios e tudo mais." (Victor "Sier" Reis - Aspirante a jogador profissional de League of Legends)

Financeiramente, os clubes não se beneficiariam apenas com as receitas originárias dos torcedores, que não podem ser subestimadas, mas também de premiações, patrocínios específicos ao clube na modalidade, ou da expansão de acordos de patrocínios de outras modalidades esportivas para os e-sports. 


\section{Conclusões}

Este estudo visou identificar as principais barreiras enfrentadas pelo segmento dos e-sports no Brasil, assim como sugestões para sua superação. Para isso, foram utilizadas como referências, reportagens veiculadas em plataformas online sobre os e-sports e entrevistas qualitativas com profissionais envolvidos com a atividade, que foram analisadas com o referencial teórico de Porter $(1989,2004)$ sobre indústrias emergentes.

É importante destacar que as conclusões e sugestões obtidas são limitadas, devido ao tamanho e natureza da amostra de pesquisa.

Os e-sports tiveram seu crescimento acelerado com o desenvolvimento da rede mundial de computadores e do acesso da população mundial aos computadores e consoles, tornando-se um mercado que se encontra em elevado crescimento por todo o mundo, porém, de forma ainda tímida em regiões como o Brasil.

Há diversos títulos e tipos de jogos eletrônicos nos e-sports. Alguns possuem maior número de adeptos, fãs, torcedores e competições, como é o caso do League of Legends, que foi utilizado como foco principal desde trabalho devido ao seu tamanho em comparação aos outros e por ser "a única liga que se assemelha a instituições esportivas tradicionais, apresentando temporadas competitivas agendadas, restrições obrigatórias sobre negociações com jogadores, regras para a venda de franquias/equipes, entre outros." (Bester, 2017).

Esse trabalho buscou evidenciar e esclarecer as semelhanças e diferenças dos e-sports com os esportes já tradicionais. As principais semelhanças evidenciadas estão na competitividade, dedicação e disciplina empregada nos treinos, tal como em qualquer outro esporte. Além disto, a atividade é um substituto como meio de entretenimento em relação a outros esportes. Por outro lado, para os participantes, a intensidade física que ocorre em sua prática tende a ser inferior à dos esportes tradicionais, sendo esse um dos principais argumentos sobre se os e-sports devem ou não ser considerados esportes. 
Através da pesquisa e entrevistas realizadas, foi possível perceber que os e-sports no Brasil ainda enfrentam diversas barreiras que diminuem a velocidade do seu desenvolvimento.

As principais barreiras identificadas foram relacionadas à crise econômica que vem assolando o país nos últimos anos; a forma como é feita a prática dos e-sports, que, por possuir diferenças com relação aos esportes já tradicionais acaba por gerar preconceitos para com os seus praticantes; as barreiras demográficas e infraestrutura defasada das conexões banda larga do país com relação às regiões mais desenvolvidas, tal como o alto custo dos hardwares para a população; e a mídia que até pouco tempo produzia conteúdos que expunham de forma negativa a prática dos e-sports.

A pesquisa documental indicou que $98 \%$ da receita mundial dos e-sports provem da América do Norte, Europa e Ásia, e tal concentração se deve à falta de investimentos das grandes empresas multinacionais nos e-sports em outras regiões, como no Brasil. Segundo apurado nas entrevistas, muitas empresas grandes ainda não investem na atividade, o que pode se dever a fatores como: a prematuridade do mercado brasileiro, que ainda não se compara as outras regiões e que ainda deixa tais empresas incrédulas quanto à seriedade dos profissionais brasileiros, além da crise econômica pela qual o país vem passando, que deixa os recursos para investimentos em patrocínios e divulgação limitados, o que acaba fazendo com que essas empresas busquem investimentos em formas mais seguras de divulgação das suas marcas.

Algumas sugestões para a superação das barreiras são o investimento das organizações já envolvidas com os e-sports no Brasil em mídias televisivas, principalmente em canais de televisão aberta, assim como o investimento na criação de novos torneios além do principal que é o CBLOL. Espera-se assim, gerar uma maior visibilidade das marcas que patrocinam e apoiam os e-sports para que sejam difundidos mais interesses em investimentos, patrocínios e apoios por parte de empresas que ainda não aderiram aos e-sports.

Pelas reportagens pesquisadas e entrevistas feitas com os profissionais, ficou evidente que parte da população ainda possui preconceitos para com os profissionais dos e-sports o que se deve pela grande massa da população ainda não considerar os e-sports como esportes, e por acreditarem que ainda não existem profissões a serem seguidas nesse meio como em outros esportes.

Para mudar a percepção da população e melhorar a imagem dos e-sports, seria importante haver uma maior divulgação através das mídias. Algumas sugestões seriam: a produção de reportagens positivas, maior divulgação e 
transmissão dos torneios (principalmente na TV aberta) e até mesmo a criação de personagens em novelas que sejam gamers ou pro-players sem os atuais estereótipos. Outra possibilidade seria permitir uma maior proximidade do público aos pro-players durante seu treinamento.

No Brasil grande parte da população reside em regiões onde 0 fornecimento do serviço de internet é de baixa qualidade, com baixa velocidade ou instável, o que prejudica o mercado, seja atrapalhando o desenvolvimento de jogadores de e-sports, seja o acesso e qualidade da experiência do público às transmissões dos campeonatos. Além da internet, apenas metade dos lares brasileiros possui computadores (como apurado pela pesquisa da TIC Domicílios no ano de 2015) e grande parte provavelmente possui computadores com hardwares de capacidade insuficiente para jogos como o League of Legends.

O investimento em transmissões na televisão aberta ajudaria a tornar os esports mais conhecidos e acessíveis para a população, principalmente para aqueles que não possuem computador em casa ou dispõem de internet de baixa qualidade. Quanto ao desenvolvimento da infraestrutura necessária para o fornecimento de banda larga de qualidade para a população, a indústria dos esports não possui ação direta, mas poderia influenciar indiretamente pela maior exigência por parte dos seus praticantes diante das fornecedoras desse serviço, assim como já é notado na indústria de computadores pessoais.

Para uma maior difusão dos e-sports na TV aberta, uma sugestão seria um aporte financeiro inicial das empresas envolvidas atuantes no Brasil para investimentos na produção de matérias e transmissões dos torneios. Com o tempo, espera-se que apareçam patrocinadores, tornando os e-sports lucrativos para a televisão aberta.

Foi interessante perceber o quanto as organizações esportivas têm a ganhar investindo nos e-sports, seja com times próprios ou com parcerias com times já consolidados, o que poderia expandir sua base de torcedores, além de gerar receitas com vendas de produtos complementares como uniformes e souvenires específicos dos e-sports, ou mesmo da possível expansão dos contratos com seus atuais patrocinadores aos times de e-sports.

\subsection{Recomendações para novos estudos}

O estudo trouxe informações relevantes acerca do mercado brasileiro de esports, tal como algumas razões para seu atual estágio de desenvolvimento, 
considerado como atrasado em relação às regiões onde eles são mais desenvolvidos.

A metodologia utilizada pode ser replicada tanto para a análise de outras indústrias emergentes, como para a busca de novas alternativas de desenvolvimento para os e-sports no Brasil.

No campo das finanças, uma linha adicional de investigação seria a identificação dos retornos financeiros com investimentos nos e-sports no Brasil.

No campo do marketing, seria interessante uma pesquisa qualitativa e quantitativa com a população para identificar seu nível de reconhecimento dos esports, identificando quantos sabem do que se tratam os e-sports, quantos 0 consideram de fato como um esporte e qual sua relação com a modalidade.

Finalmente, seria interessante identificar a evolução da migração da audiência dos esportes tradicionais para os e-sports por meio de canais esportivos como o ESPN e Sportv. 


\section{Bibliografia}

Academia Hawkon. A história do e-sports mundial. São Paulo, 05 out. 2015. Disponível em: <http://www.hawkongaming.com.br/single-post/2015/10/06/AHistoria-do-eSports-Mundial>. Acesso em: 17 de março. 2017.

ALMEIDA, A. Oito clubes da Bundesliga podem investir no eSports. Esporte Interativo, São Paulo, 5 out. 2017. Disponível em: $<$ http://esporteinterativo.com.br/esports/oito-clubes-da-bundesliga-podeminvestir-nos-esports/>. Acesso em: 16 de março. 2017.

BESTER, Alan. Os erros e acertos de "League of Legends", "CounterStrike" e outros principais títulos do eSport. ESPN, São Paulo, 27 de ago. 2017. Disponível em: <http://ESPN.uol.com.br/noticia/721971_os-erros-eacertos-de-league-of-legends-counter-strike-e-outros-principais-titulos-do-

esport> Acesso em: 28 de agosto. 2017

Bocchini, B. Pesquisa mostra que $58 \%$ da população brasileira usam internet. Agência Brasil, São Paulo, 13 set. 2016. Disponível em: < http://agenciabrasil.ebc.com.br/pesquisa-e-inovacao/noticia/2016-09/pesquisamostra-que-58-da-populacao-brasileira-usam-internet>. Acesso em: 30 de out. 2017.

BRIGATOO, G. Jogos tiram do marasmo o setor de computadores. Valor Econômico, São Paulo, 13 de out. 2017. Disponível em: <http://www.valor.com.br/empresas/5154488/jogos-tiram-do-marasmo-o-setorde-computadores> Acesso em: 15 de outubro. 2017

COUNTER STRIKE. Wikipédia. Disponível em: $<$ https://pt.wikipedia.org/wiki/Counter-Strike_(serie)>. Acesso em: $11 \mathrm{de}$ novembro de 2017

Dictionary.com. $\quad 2017 . \quad$ Disponível em: <http://www.dictionary.com/browse/esports?s=t>. Acesso em: 20 de junho. 2017.

DOTA 2. Wikipédia. Disponível em: <https://pt.wikipedia.org/wiki/Dota_2>. Acesso em: 11 de novembro de 2017 
Equipe HDBR. CGI.br divulga mapa da Banda "Larga" no Brasil. São Paulo, 2011 Disponível em: <http://blog.hostdime.com.br/noticias/novidades/cgi-brdivulga-mapa-da-banda-larga-no-brasil/>. Acesso em: 22 de junho. 2017.

FABER, R. Mais leve, Takeshi supera "pedradas" e enxerga Keyd pronta para o título. Sportv, São Paulo, 06 mar. 2017. Disponível em: <http://sportv.globo.com/site/games/noticia/2017/04/mais-leve-takeshi-superapedradas-e-enxerga-keyd-pronta-para-o-titulo.html>. Acesso em: 07 de abril. 2017.

FRANCESCHINI, G. Como e por que Ronaldo Fenômeno decidiu investir em e-sports? Uol, São Paulo, 31 jan. 2017. Disponível em: <https://esporte.uol.com.br/ultimas-noticias/2017/01/31/como-e-por-que-ronaldofenomeno-decidiu-investir-nos-e-sports.htm>. Acesso em: 16 de março. 2017.

G1. Banda larga no Brasil. Rio de Janeiro, 2016 Disponível em: <http://especiais.g1.globo.com/tecnologia/banda-larga-brasil/2015/>. Acesso em: 22 de junho. 2017.

LEAGUE OF LEGENDS. Wikipédia. Disponível em: <https://pt.wikipedia.org/wiki/League_of_Legends>. Acesso em: 11 de novembro de 2017

Leister Filho, Adalberto. Estados Unidos emplaca 4 das 5 maiores ligas do mundo em faturamento, diz site. Máquina do esporte, São Paulo, 05 de jul 2016. Disponível em <http://maquinadoesporte.uol.com.br/artigo/estados-unidosemplaca-4-das-5-maiores-ligas-do-mundo-em-faturamento-diz-site_30695.html> acesso em 16 de outubro. 2017

Melo, G. Audiência da decisão do CBLOL 2017 supera a da edição passada. MY CNB, São Paulo, 13 set. 2017. Disponível em: <http://mycnb.uol.com.br/noticias/6015-audiencia-da-decisao-do-cblol-2017supera-a-da-edicao-passada>. Acesso em: 29 de outubro. 2017.

MY CNB. Riot diz que League of Legends tem 100 milhões de jogadores. Rio de Janeiro, 13 de set 2016 Disponível em: <http://mycnb.uol.com.br/noticias/4623-riot-diz-que-league-of-legends-tem-100milhoes-de-jogadores>. Acesso em: 25 de junho. 2017.

OVERWATCH. Wikipédia. Disponível em: <https://pt.wikipedia.org/wiki/Overwatch>. Acesso em: 11 de novembro de 2017 
PACETE, L. O que levou Ronaldo a investir em e-sports? Meio\&mensagem, São Paulo, 09 fev. 2017. Disponível em: <http://www.meioemensagem.com.br/home/marketing/2017/02/09/_trashed16.html>. Acesso em: 16 de março. 2017.

PALAZUELOS, Félix. Os "e-sports" poderão virar modalidade olímpica nos jogos de Paris. EL País (Edição Brasil), São Paulo, 21 ago. 2017. Disponível em:

<https://brasil.elpais.com/brasil/2017/08/19/tecnologia/1503139023_302525.html >. Acesso em: 15 de outubro. 2017.

Pesquisa Game Brasil. Perfil do gamer brasileiro. Brasil, 2017. Disponível em: <https://www.pesquisagamebrasil.com.br/pesquisagamebrasilgratis>. Acesso em: 27 de junho. 2017.

PORTER, Michael E. Estratégia competitiva: técnicas para análise de indústrias e da concorrência. $2^{\underline{a}}$ ed. Rio de janeiro: Elsevier, 2004

PORTER, Michael E. Vantagem competitiva: criando e sustentando um desempenho superior. 43를 ed. Rio de Janeiro: Elsevier, 1989

RIGON, Daniela. Crescimento do Brasil e desafios do CBLOL: uma conversa com Peter Dun, técnico da INTZ. ESPN, São Paulo, 16 de ago. 2017. Disponível em: <http://ESPN.uol.com.br/noticia/719294_crescimento-dobrasil-e-desafios-do-cblol-uma-conversa-com-peter-dun-tecnico-da-intz> Acesso em: 18 de ago. 2017

Superdata Research. eSports Market Report. Estados Unidos, 2016. Disponível em: $\quad<$ https://www.superdataresearch.com/market-data/esports-market-brief/>. Acesso em: 16 de maio. 2017.

VENDRAMINI, Daniela. Afinal, pela Lei Pelé, o eSport, já é um esporte? ESPN, São Paulo, 16 de ago. 2017. Disponível em: <http://ESPN.uol.com.br/noticia/719226_afinal-pela-lei-pele-o-esport-ja-e-umesporte >. Acesso em: 18 de ago. 2017

VINHA, F. Entenda o que é eSport e saiba como ele virou uma febre mundial. Techtudo, São Paulo, 28 out. 2015. Disponível em: $<$ http://www.techtudo.com.br/noticias/noticia/2015/10/entenda-o-que-e-esport-esaiba-como-ele-virou-uma-febre-mundial.html>. Acesso em: 17 de março. 2017. 


\subsection{Anexos}

\subsubsection{Questionário}

1) O que é o e-sport para você?

2) (Observando o gráfico a seguir) O que você acha que a Ásia, América do Norte e Europa têm que fazem dos e-sports muito mais desenvolvidos nessas regiões?

\section{Faturamento dos e-sports por região no ano de 2016}

Worldwide eSports revenues by region, 2016E

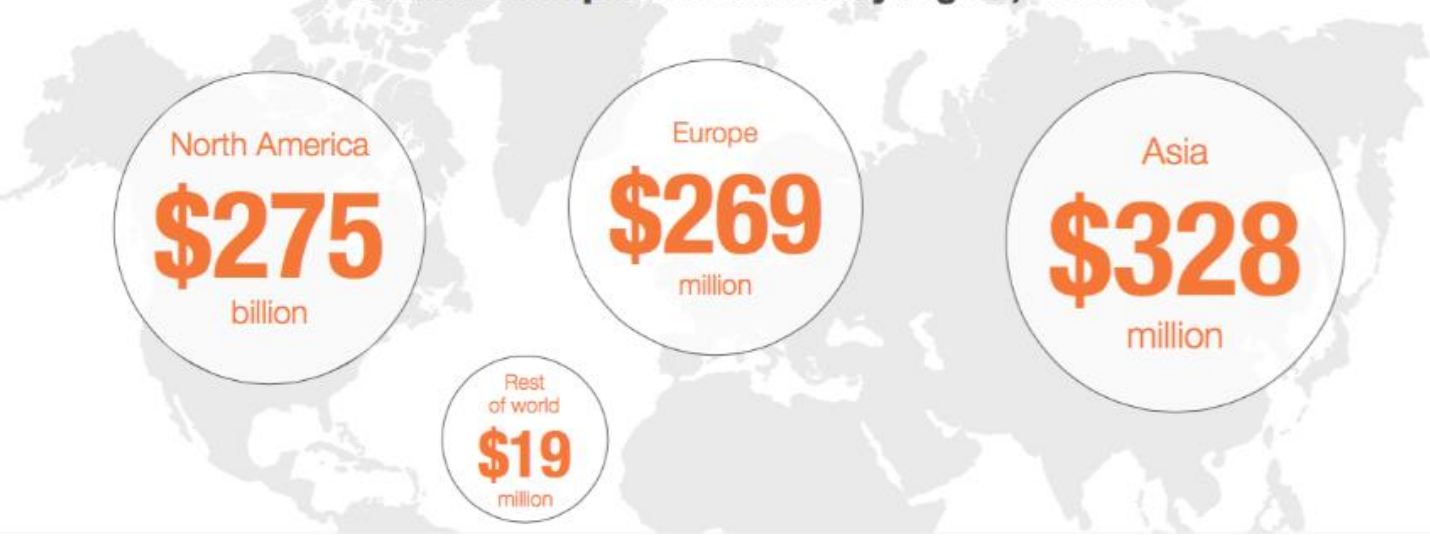

3) Você acha que a população vê os e-sports como um esporte? Há preconceito? Algum caso que gostaria de destacar?

4) Quais as principais barreiras para a atividade ser considerada um esporte? (emprego muito intenso de tecnologia? Pouco esforço físico pelos participantes?)

5) O que as empresas envolvidas com e-sport no Brasil poderiam fazer para vencer o preconceito ainda existente no país?

6) O que você acha que também contribuiria mais para o desenvolvimento do e-sport no Brasil?

- Melhorar a Infraestrutura das conexões de banda larga do Brasil?

- Reduzir o custo dos hardwares?

- Divulgação pela mídia: canais a cabo, canais abertos?

Exemplos? 
7) Acha que as torcidas dos clubes esportivos do Brasil torceriam por seus times também no e-sport ou acha que para a torcida que não acompanha o e-sport isso seria irrelevante ou poderia ser visto de forma negativa?

8) O que você acha desse momento para investir no cenário brasileiro de e-sport? Por quê?

9) Qual a percepção inicial dos seus familiares quando você começou a sua carreira dentro desse cenário e qual a percepção atual deles? E o que você acha que foi importante para essa mudança? 